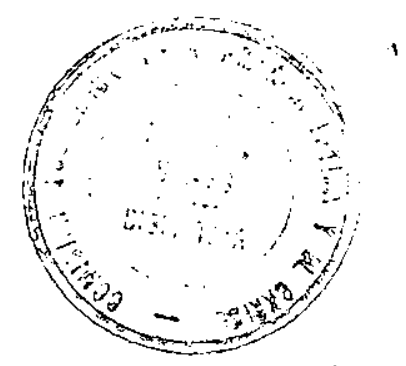

\title{
AN OVERVIEW ON DEBT MORATORIA IN LATIN AMERICA
}

\author{
Oscar Altimir* \\ Robert Devlin<smiles>[C]1C2C[C@H]12</smiles>

\section{Working Paper No.6 ** \\ June 1992}

\begin{abstract}
* The authors are respectively Director and Senior Economist in the Economic Development Division of ECLAC. The paper is the exclusive responsibility of the authors and does not necessarily reflect the opinions of ECLAC. A version of this paper was presented to a meeting of the International Political Science Association, 21-21 July 1991, in Buenos Aires, Argentina. We very much thark Rosella Cominetti, Felipe Jiménez, Carlos Massad, Arturo O'Connell, Kenrick Paul, and Elena Solminihac for their helpful comments, and Guillermo Mundt and Luis Alberto Santa Cruz for their statistical help.
\end{abstract}

** The purpose of the papers in this series is to provide a preliminary report on ECLAC research findings as a basis for comments and suggestions. This publication is not an official document and has therefore been reproduced without formal editing. It may be requested directly from the ECLAC Economic Development Division.
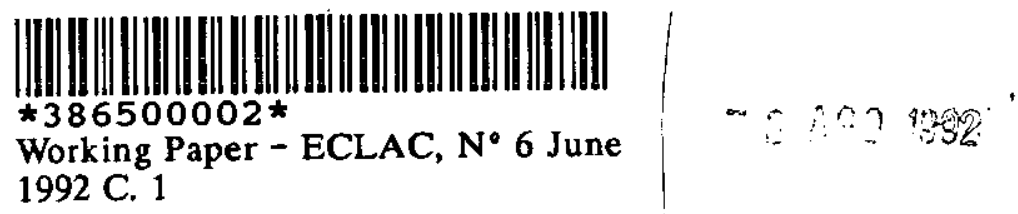

Contents

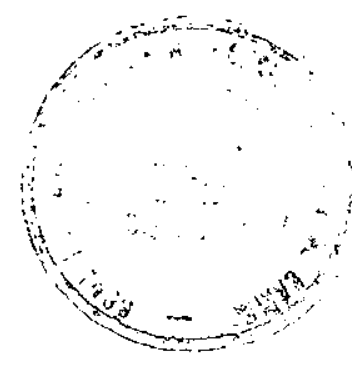

Page

I. INTRODUCTION $\ldots \ldots \ldots \ldots \ldots \ldots \ldots \ldots \ldots \ldots \ldots$

II. THE EMERGENCE OF DEBT MORATORIA $\ldots \ldots \ldots \ldots \ldots \ldots$

III. THE STRUCTURAL BACKGROUND OF LATIN

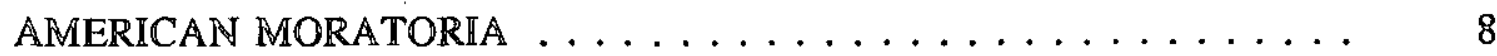

IV. THE ADMINISTRATION OF THE MORATORIUM $\ldots \ldots \ldots \ldots \ldots$

A. The tone of the moratorium $\ldots \ldots \ldots \ldots \ldots \ldots \ldots \ldots$

$\mathbb{B}$. The queue for payments $\ldots \ldots \ldots \ldots \ldots \ldots \ldots \ldots$

C. Defensive measures . . . . . . . . . . . . . . . . 19

1. International reserves . . . . . . . . . . . . . . . 19

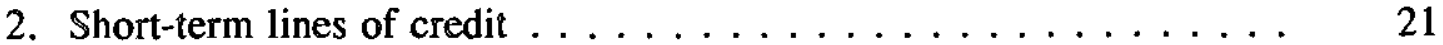

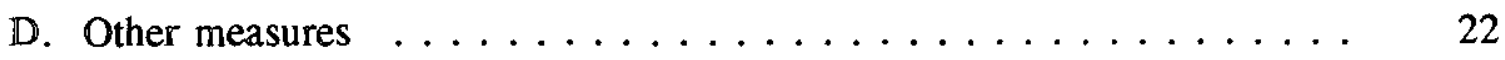

V. THE EFFECTIVENESS OF THE MORATORIUM STRATEGY $\ldots \ldots .22$

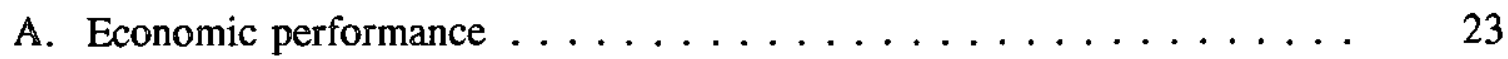

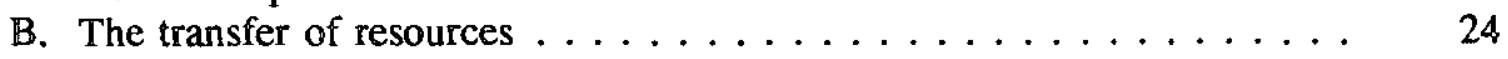

C. The effectiveness of defensive measures $\ldots \ldots \ldots \ldots \ldots \ldots 25$

D. The moratorium as political tool . . . . . . . . . . . . 27

E. The effectiveness of moratoria as a bargaining tool . . . . . . 28

VI. CONCLUSIONS ......................... 29

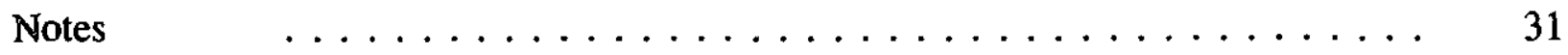

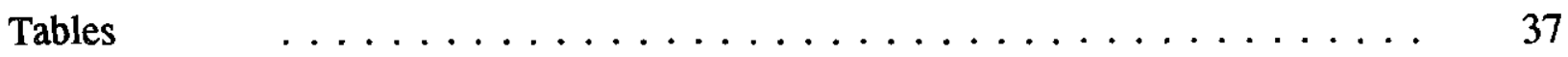

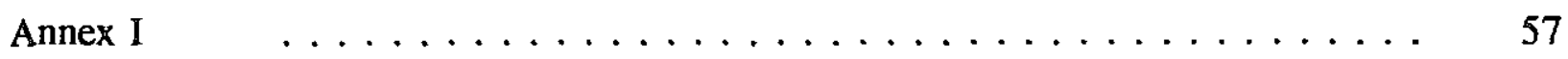

Bibliography $\quad \ldots \ldots \ldots \ldots \ldots \ldots \ldots \ldots \ldots \ldots \ldots \ldots \ldots \ldots \ldots$ 



\section{INTRODUCTION}

The history of international capital markets is replete with cycles of credit booms and crashes (Kindleberger, 1978; Galbraith, 1975). Latin America has often been an active player in the checkered performance of these markets; indeed, the region's access to international credit was ended by defaults in the late 1820s, late 1880s, the 1890s, and the early 1930s (ECLAC, 1965). The latest crisis of course broke out in August 1982 when a serious debt servicing problem in Mexico --then the world's second largest developing-country debtor-- sparked a systemic financial collapse in Latin America, the negative repercussions of which are still being felt today (ECLAC, 1990b).

The problems of the 1980s in many ways followed the traditional pattern of financial crisis: euphoric borrowing and lending followed by payment difficulties, defaults and moratoria. However, the period also was characterized by a major novelty: the emergence of an international-lender-of-last-resort (ILLR), which helped to delay many formal defaults and moratoria, thereby allowing creditors to evade the destabilizing losses that normally have accompanied systemic financial crises. ${ }^{1}$

The action of the ILLR --in this case led by the United States Government-- worked quite effectively in the early 1980 s in avoiding the formal defaults that could have toppled major international commercial banks and played havoc with world output. ${ }^{2}$ The precise mechanisms deployed by the ILLR are relatively well known. First, the commercial banks --the region's main creditor-- grouped together behind their Advisory Committee of lead banks to reschedule debt service through principal restructuring and partial refinance of interest payments (termed "involuntary lending"). Moreover, the terms of the reschedulings were commercial, indeed more correctly punitive, in nature. ${ }^{3}$ Second, bilateral debt was rescheduled through the Paris Club. Third, new lending was mobilized from the multilateral agencies to partially refinance scheduled debt service. Fourth, the debt reschedulings and new money packages were cross-conditioned by the signing of a standby agreement with the IMF; the Fund's adjustment programme in turn deflated the debtors' economies and produced a large trade surplus for the service of interest payments. Finally, the United States Treasury and the Bank for International Settlements organized short-term bridge loans which provided the interim refinancing needed to avoid formal defaults during the complex debt restructuring negotiations. ${ }^{4}$

The coordination of the banks and other creditors was relatively tight, indeed cartel-like. As an instrument to save the international financial system, the ILLR worked quite well. The rescheduling/refinancing of debt service on rather lucrative commercial terms, coupled with draconian adjustment measures in the debtor countries, helped the banks to avoid losses; indeed, Latin America ironically became a profit centre for these institutions during their worst financial crisis since the 1930 s. $^{5}$

The initial reschedulings of $1982 / 1983$ incorporated practically all the debtor countries of the region. However, in four subsequent rounds of reschedulings in the period 1983-1990 progressively fewer countries participated in the official debt management program. ${ }^{6}$ The other 
side of the coin of this growing rate of attrition was the accumulation of arrears in the service of foreign debt. The arrears build-up in the region, on interest payments alone, exceeded US\$ 25 billion by the end of 1990 , and accounted for $20 \%$ of the debt accumulated since 1981 (see tables 1 and 2). At least US\$ 21 billion of the unpaid interest was with the commercial banks; the rest affected government creditors and multilateral lenders. In 1990 the only countries fully current on their debt service for the entire year were Chile, Mexico, Colombia and Uruguay. ${ }^{\text {? }}$

The build-up of arrears effectively represented the emergence of a quiet moratorium ${ }^{8}$ in Latin America. In contrast with the 1930s, when the stoppage of payments by major debtors was relatively sudden and massive, ${ }^{9}$ the defaults of the 1980 s have emerged gradually and parallel with the official debt rescue program's increasing inability to adapt itself to the deteriorating situation of most of the debtor countries. Moreover, defaults were staved off long enough to allow the banks to build defenses through the provision of loan loss reserves and increases in their capital base. Consequently, although sometimes troublesome, the arrears in the region have not been life threatening to the financial system or to most individual lenders.

Even though most countries in Latin America have fallen into some type of moratorium, there has been relatively little study of the phenomenon. This is perhaps due to the great stigma that financial circles attach to a moratorium and the fact that the payments restrictions have emerged gradually, mostly with little fanfare, and with little threat to Northern financial systems. This paper overviews the issue of moratorium in the region, with a view to arriving at some tentative general conclusions about the "why" and "how" of the payments restrictions and their impact on economic adjustment and the renegotiation of the external debt.

\section{THE EMERGENCE OF DEBT MORATORIA IN LATIN AMERICA}

The shock of Mexico's debt service problems in 1982 rippled through the financial system and caused a dramatic restriction of private credit. This, coupled with falling prices for exports and high real interest rates, induced practically all the Latin American countries to seek debt relief from their creditors. The most notable exception was Colombia, which had gained a reputation for extremely cautious debt management; its relatively benign debt profile allowed it to escape the wave of reschedulings. ${ }^{10}$

What is striking about 1982 is that with the explosion of the worst financial crisis since the 1930s there was no major outbreak of interest arrears in Latin America (see tables 1 and 2). ${ }^{11}$ This was largely due to the comprehensiveness of the actions taken by the ILLR. Indeed, the only principal sources of a serious accumulation of arrears in 1982 --Costa Rica, Nicaragua, and Bolivia-- ${ }^{12}$ actually were manifestations of debt-servicing problems that had emerged with the banks and the Paris Club countries prior to the great financial crisis. Moreover, the ILLR brought Costa Rica into the first round of reschedulings and thereby helped it reduce its arrears to nearly zero in 1983 . 
There was a bulge in arrears in late 1983, largely due to events in Argentina --the third biggest developing-country debtor (see again table 1). A military government had negotiated a rescheduling agreement in principle during the first round of these exercises. However, implementation became blocked by a failure to comply with IMF targets --which, in turn, paralyzed the disbursement of involuntary loans-- and by disagreements with the banks over details of the restructuring agreement itself (Bouzas and Keifman, 1988). A rapid drain of international reserves induced arrears with the banks in October 1983. Resolution of the problem was left to the new democratic government of Raúl Alfonsín, which entered power in December of that year.

The new authorities decided not to accept the onerous rescheduling agreement negotiated with the banks by the former military regime; indeed they attempted to change the prevailing rules of the game --very favourable to the bank cartel-- through a "radicalization" of the debt negotiations (Bouzas and Keifman, 1988) . A continued accumulation of arrears with the banks emerged as part of the bargaining for a better deal. The Argentine Government was also instrumental in the formation, in early 1984, of a group of Latin American debtors --dubbed the Cartagena Consensus-- which attempted to construct a regional position on some of the major issues surrounding the debt crisis. $^{13}$ Finally, the country even presented a unilaterally formulated adjustment programme to the IMF (Machinea and Sommer, 1992).

The Argentine negotiations were the first serious public challenge to the difficult terms imposed by the banks and the ILLR in the first two rounds of reschedulings. ${ }^{14}$ But heavy pressure from the banks and the ILLR, coupled with a deteriorating domestic economic programme and the limited disposition of other major debtors to follow Argentina's tougher bargaining position, caused the struggle to gradually peter out and formally end in late 1984 when the country joined the rest of the region in signing on to the third round of debt restructuring accords. The new terms offered Argentina were somewhat more generous than those agreed to in the first round of reschedulings and also established a way to begin eliminating the country's serious accumulation of interest arrears (see table 2). However, the terms of the new rescheduling accord were merely in line with the pattern established by Mexico at mid-year in its new accord with the banks, which emerged only after very difficult negotiations. ${ }^{15}$ The concessions granted Mexico and other debtors helped to isolate the recalcitrant Argentine authorities, as well as to forestall any possibility of the Cartagena Consensus evolving into a debtors'cartel (Devlin, 1989).

Although much of the creditors' efforts in 1984 were concentrated on avoiding a protracted default in megadebtor Argentina, problems were emerging for some of the smaller countries of the region. During the first half of 1984 the Belaúnde government in Peru failed to comply with its IMF targets, which paralyzed new disbursements from that organization and the banks. That in turn induced the beginning of a quiet moratorium in a country which heretofore had been one of the most cooperative debtors in the region. By the end of the year the government had accumulated interest arrears which accounted for $13 \%$ of the growth in outstanding debt (see table 2). 
Meanwhile, Bolivia formalized its moratorium on the service of debt to the commercial banks and the Paris Club countries. After a major rescheduling with the banks in 1981, the country had begun once again to fall behind in its payments in late 1982. An interim agreement with the banks to normalize payments avoided a moratorium. However, in the last quarter of 1983 the country failed to make a payment. This was followed by another interim agreement to reestablish payments in 1984. However, the collapse of the tin market eroded whatever capacity to pay that was left; in May the banks were informed by telex that the country was not able to make even partial payments. Then in June the Siles Zuazo government, in a political pact with Bolivia's powerful labor union, announced its intention to limit debt service to $25 \%$ of exports (Cariaga, 1992). It also joined Argentina in pushing for concerted regional action on the debt through the Cartagena Consensus. By the end of 1984 arrears in that country accounted for $18 \%$ of the accumulation of debt (see table 2).

During 1984 Costa Rica once again experienced troubles with the IMF and its debt service. However, the signing of new accords with the Fund and other creditors during the third round of reschedulings once again allowed it to regularize payments.

New rescheduling agreements also gave the Dominican Republic an opportunity to regularize payments. On the other hand, even though Honduras had reached a rescheduling agreement in principle with the banks, it continued to fall behind in payments because of problems with the IMF. Meanwhile, Paraguay's payment problems with certain Paris Club countries, originally considered temporary in nature, began to take on a more permanent character. And, of course, there was little hope of war-torn Nicaragua reversing its steady accumulation of arrears to nearly all creditors (see table 1 ).

The success of the third round of rescheduling in containing arrears, coupled with the strong growth of the United States economy in 1984, led some to conclude by early 1985 that the debt problem was over (Hector, 1985). The problem fronts that remained were in a few smaller countries like Bolivia, Nicaragua and Peru. Moreover, the most important of these -Peru-- was expected to regularize its payments after the inauguration of a new government in mid-year. However, serious problems developed as the year progressed.

The continuing weight of the debt began to stir unrest in Mexico and Brazil; this latter country even began to withhold payments to the Paris Club countries. ${ }^{16}$ In addition, Cuba started a highly publicized campaign in which it argued that the region's debt was unpayable and should be forgiven. Meanwhile, in Peru the leading presidential candidate made the IMF and the excessive burden of the debt the central issues in his political campaign. Moreover, one of his first acts as President, after a land-slide victory, was to formalize and radicalize Peru's moratorium by announcing that the country would not go to the IMF and would also limit public debt service to $10 \%$ of exports.

The tension that grew out of these events probably explains the surprise (and improvised) announcement of the Baker Plan in September 1985 (Devlin, 1989). The Plan addressed the debtor countries' concern about the stagnation of their economies and the ever tighter 
environment for fresh credit. In effect, the new focus promised adjustment with growth. To achieve this the United States Treasury Secretary pledged to revitalize involuntary lending --which had fallen off sharply in the third round of rescheduling-- for 17 countries, most of which were Latin American. ${ }^{17}$

The Baker Plan was clearly a bold attempt to put new life into the flagging international debt strategy and to prevent other Latin American countries from following Peru's bad example. In this regard, the strategy initially worked to some extent: anticipation of the benefits of the new Plan helped to calm the debate around the debt issue. However, the Baker Plan in fact marked the beginning of a serious breakdown in the official management of the debt problem.

The Plan had a difficult take-off. By late 1985 many banks had discarded the possibility of a quick economic turnaround in the region and they also were in a better position to absorb delays in payments; the banks therefore strongly resisted the new involuntary lending proposed by Mr. Baker. Indeed, the Plan's pilot rescheduling in Mexico came about only in mid-1986 after a very serious threat of a moratorium in that country and the direct intervention of the Chairman of the United States Federal Reserve, who literally "informed" the banks of their participation in a US\$ 13.7 billion concerted financing package for that country.

The banks, severely irritated by the government's intervention in their affairs, stated that the softer commercial terms and new money granted Mexico constituted a special case. ${ }^{18}$ Negotiations in other countries, all of which were asking for the "Mexican treatment", stalled. The stalemate contributed to the growth of moratoria in the region.

The inability to arrange an appropriate rescheduling/new money package caused Costa Rica to once again fall into a de facto moratorium, first in late 1985 with certain Paris Club countries and then with the commercial banks in 1986. Meanwhile, the marked drop in petroleum prices in late 1985 had put severe pressure on Ecuador's finances. The Febres Cordero government was a favored target for the Baker Plan. However, the failure to organize a serious new money package for this country aggravated its payment problems with the banks and creditor governments; by the beginning of 1987 there was a serious problem of arrears. A strong earthquake in March 1987, which damaged the country's trans-Andean oil pipeline, turned the lag in payments into a formal suspension of debt service. In 1986 the Dominican Republic again slid into arrears with the Paris Club governments. Cuba also added itself to the list of countries in moratorium with the banks and creditor governments, while Paraguay, already in arrears with certain governments, started to fall behind in payments to the commercial banks as well. On the other hand, in mid-1986 Bolivia started to climb out of its moratorium by negotiating a rescheduling with the Paris Club governments that included a regularization of arrears. Debt with the banks, however, remained unserviced.

A major blow for the prevailing debt strategy grew out of developments in Brazil. The Sarney administration --which had built up interest arrears with the Paris Club between January 1985 and April 1986-- saw its external situation eroded by a severe narrowing of the country's trade surplus in late 1986 due to the excessive domestic demand generated by its Cruzado Plan. 
The new economic team was skeptical of the Baker Plan and wanted to redefine the rules of the debt rescheduling game. In January 1987, it settled --thanks to the favourable intervention of the United States Secretary of the Treasury Baker-- a long dispute with the Paris Club over the IMF and rescheduled without a prior standby agreement with the Fund. However, in February 1987 the government made a surprise declaration of a moratorium on the servicing of bank debt.

The above developments in the period 1986-1987 caused a sharp rise in the region's interest arrears. The vast majority of countries (including Cuba) were behind in their debt service payments (see table 1). The figures might have been considerably worse if the announcement of the Brazilian moratorium had not jolted the banks into action: to avoid copy cats they largely reversed themselves in the negotiations and fired off a rapid set of reschedulings in Chile, Argentina, Uruguay and Venezuela.

The bulge in arrears in 1987 --and the Brazilian moratorium in particular--, coupled with competitive considerations, encouraged the banks to sharply increase their loan loss reserves. The trend was led by Citicorp, which in May 1987 announced that it would increase its reserves by $150 \%$. The reserving, moreover, induced the first generalized report of losses for the banking industry since the Great Depression. ${ }^{19}$ But, significantly, these were controlled losses that improved the bargaining position of the banks and signaled their ability to weather the threats of moratorium. ${ }^{20}$

Shifting domestic politics and a deteriorating economic programme contributed to the Brazilian moratorium's loss of momentum in the last quarter of the year. Thus, even though arrears had formally reached record levels by the end of 1987, a preliminary accord with the banks in December in fact opened up prospects of a more regular debt servicing picture in 1988.

Indeed, 1988 started out with some improvement for the creditors. At the beginning of the year, Bolivia --using donor funds-- organized a buyback of one half of its bank debt at 11 cents on the dollar. Nevertheless, arrears remained outstanding for those banks that refused to accept the country's buy-back offer. In June, Brazil also signed a global restructuring accord with the banks.

However, in Argentina a deteriorating balance of payments and delayed disbursement of loans from the banks and the IMF (due to problems with conditionality) had created a rather precarious payments position with all creditors during the latter half of 1987. Stop-gap measures --including some emergency bridge loans-- avoided a de facto moratorium. Nevertheless, the lack of adequate and predictable external financing made the payments situation unsustainable; in April the country began a de facto moratorium on the service of bank debt and certain bilateral obligations. The arrears with the Paris Club governments were largely cleared by a rescheduling at the end of 1989; meanwhile arrears continued to accumulate with the banks and reached US\$ 7 billion at the end of 1990 (see Annex, table A1). A new problem front also opened up in Panama where domestic political strife eroded an already precarious payments position. Indeed, by 1988 this country had initiated a de facto moratorium that affected nearly 
all credits and would continue into the 1990s. In sum, in contrast to expectations, the arrears picture did not improve in 1988 as regularizations in some countries were offset by problems in other countries (see tables 1 and 2).

The year 1989 began with the announcement of yet another debt strategy --the Brady Plan. The scheme promised concerted public financial and institutional support for voluntary reduction of bank debt. ${ }^{21}$ But, significantly for our purposes, it also introduced a new and more flexible official stance on arrears with the banks. As already mentioned, the official management programme had cross- conditioned the debtor country's agreements with the IMF and the banks. However, the Brady Plan established new rules of the game which in principle made it possible, on a-case-by-case basis, to delink an $\mathbb{M M F}$ programme and other official lending from a prior debt agreement with the banks. Indeed, the new scheme permitted a temporary official toleration of arrears in cases where countries were willing to negotiate an adjustment programme with the Fund. This strategy in fact represented the generalization of a policy which had been quietly experimented with in Bolivia and Costa Rica, two countries in moratorium with the banks since 1984 and 1986 , respectively.

The new policy gained immediate expression. In early 1989 Mexico --current on its debt service-- initiated an adjustment programme with the IMF and a rescheduling with the Paris Club before reaching an agreement with the banks later in the year for a Brady-style debt reduction. ${ }^{22}$ That same year Ecuador and Argentina signed agreements with the Fund even while they were in serious arrears with the banks. Both countries did, however, agree to partially service their bank debt: Argentina pledged US\$40 million per month and Ecuador US\$ 13 million, equivalent to about one-third of scheduled service. They also regularized their arrears with the Paris Club governments through new rescheduling accords. Meanwhile, Costa Rica and Bolivia continued to have an official umbrella over their protracted arrears with the banks while the former negotiated a Brady package and the latter organized a donor-financed buy-back of another quarter of its bank debt (at 11 cents on the dollar). Finally, towards the end of the year Brazil quietly fell into a de facto moratorium with the banks. The Dominican Republic did the same.

Although the arrears problem in the region affected all types of creditors, about three quarters of the unpaid obligations were with commercial banks. After their unpleasant experience with the IMF in the Mexican negotiations, the banks decided to go on the offensive against the new official policy, which delinked official loans from the problem of arrears with the commercial lenders. Indeed, in May 1990 commercial lenders sponsored an important report which literally pronounced that "arrears are not the way" (Institute for International Finance, 1990). The commercial lenders increased the pressure during the rest of 1990 as considerable arrears were built up in Brazil and the new Collor government hardened its bargaining position on the foreign debt.

While interest arrears rapidly accumulated in Brazil --reaching nearly 10 billion by the end of 1990-- other countries advanced in their negotiations. Costa Rica finalized a Brady debt reduction accord which included a rescheduling of all arrears. Venezuela, which at the 
beginning the year had been accumulating arrears under an IMF umbrella, also negotiated a debt reduction accord with the banks. Another accord was implemented in Uruguay (current on its debt service), while Chile (also current) chose to reschedule its bank debt. ${ }^{23}$ Meanwhile, Argentina increased its debt service to the banks to US\$ 60 million per month.

At the same time new mechanisms also were introduced to deal with arrears with multilateral lenders. A governmental consultative group provided bridge loans to Honduras to help it eliminate arrears with these lenders and negotiations were initiated to form official support groups with similar goals for Peru and Nicaragua. Peru moreover renewed its debt service to the multilateral lenders, which at least froze its interest arrears to these institutions at about US\$ 500 million. Later in 1991 Nicaragua and Peru would reach agreements with their respective support groups and the two countries would also regularize themselves with the Paris Club (O'Connell, 1992).

By the end of 1990 it also had become clear that the pressure being applied by the banks was having some effect. Brazil found that its arrears with the commercial lenders were contributing to problems in signing an IMF agreement. Moreover, the World Bank and the Inter-American Development Bank (IDB) began to condition their loans to the reaching of an agreement with the banks over accumulated arrears. The official pressure was a factor in Brazil's arriving at an agreement with the banks in early 1991. In effect, Brazil agreed to pay in cash US\$2 billion of interest arrears accumulated up through 1990 and convert the balance (US\$ 6 billion) into 10-year bonds when the country managed to formalize a Brady accord, perhaps in 1992 (de Freitas, 1992). These events in Brazil --which relinked official lending to a prior agreement with the banks-- signaled a reversal in perhaps the most innovative feature of the Brady Plan.

Looked at from another angle, the pragmatic gray zone for payments established by the Brady Plan became threatened by the more black-and-white perspective of the banks. As the Director of the Institute of International Finance, an organization of the banking community, recently stated: "The system cannot work, however, for those countries that choose to disregard its rules.... There is only one standard: either you fulfill your contractual obligations or you don't." (LDC Debt Report, 1991).

\section{THE STRUCTURAL BACKGROUND OF LATIN AMERICAN MORATORIA}

The debt crisis that spread over Latin America in the beginning of the 1980 s was one of the special features of the worldwide recession of 1980-1983. However, even though the world economy recovered from that setback, the debt problem of Latin American countries lingered on. Moreover, as just shown, in their muddling through this problem, most of the countries entered into either formal or de facto moratoria on the service of their external debt. Our contention is that these payments problems, as well as the heavy indebtedness of the previous decade, must be read against the background of structural imbalances which have characterized, 
in each national case, the development of Latin American economies and which also have been aggravated by the crisis itself.

Krueger (1987) points out that the explanations of what went wrong in the early 1980 s can be divided into the following groups: those focusing on the unsustainability of the debt build-up in the 1970 s (thereby implicitly blaming the policies of the debtor countries); those pointing to the unexpected changes in the world economy in the early 1980s; and those centering on developing countries' unwillingness or inability to adjust to the "harsher economic realities of the $1980 \mathrm{~s}^{\prime \prime}$.

We agree with this characterization, as well as with Krueger's stance that the important question is how much weight should be attached to each of these factors. However, we add an important caveat: the blaming of domestic policies --both for their role in building up an unsustainable debt and in the eventual inability to adjust-- should be understood in the context of the persistence of structural imbalances; the deficiencies of many of the conditions imposed by multilateral lenders; the extreme shortsightedness of creditor banks; and the domestic political constraints on the adoption of quick and effective economic policies. In other words, instead of thinking of a rather ethereal economic policy in which failure or success in solving economic imbalances is to be absolutely blamed or praised on technical grounds, we conceive economic policy responses as taking place not only amid structural --and, hence, hard to solve-imbalances, but also in the context of institutionally conditioned policy regimes in which reform itself is eventually part of the needed structural changes. Moreover this reform and its costs confront an array of political interests supporting or opposing each policy measure.

Thus, our view is that the debt build-up essentially originated in the structural tendencies of most Latin American economies to accommodate external, saving and fiscal imbalances which were greatly amplified during the 1970 s when a permissive international financial environment induced a massive expansion of liquidity. Of course, the story of the debt build-up is not a onesided one in which Latin American policy-makers were the innocent victims of the corrupting commercial banks. On the one hand, existing trade, exchange, macroeconomic and fiscal policy regimes in place in most countries were functional to the operation of a structurally unbalanced style of development (Altimir, 1990); on the other hand, policy measures more often than not sacrificed fundamental stability for short-term political advantage under the benign mantle of increasing external indebtedness.

By the end of the 1970s a number of Latin American countries (Brazil, Bolivia, Mexico and Peru) had already reached very high ${ }^{24}$ debt/export ratios (see table 3), while others (Argentina, Chile, Uruguay) maintained their ratios at reasonable levels, but with unsatisfactory economic growth rates. Still others (Costa Rica, Ecuador, Venezuela) were attaining satisfactory GDP growth, with their debt outstanding at still relatively low levels, but with their mediumterm "solvency" at risk because their debt was growing faster than their exports. ${ }^{25}$ (See Krueger, 1987.) In any event, whichever was the case, most Latin American countries (Colombia being a noteworthy exception) faced the external unsustainability of their economic growth, as some analysts observed at the time (ECLAC, 1978). 
But there was another side to the question of the sustainability of the debt build-up: the fiscal one. By 1980, public and publicly guaranteed debt represented more than half of the external debt of most Latin American countries (see table 4). On the other hand, in some cases public external debt was already greater than the annual amount of total fiscal revenues. Moreover, public debt was increasing at rates well above the rates of expansion of fiscal revenues, an indication of a latent fiscal "insolvency".

Against this background, events in the international economy in 1979-1982 compounded the vulnerable situation of the countries of the region. The oil price increase of 1979 induced both a further enhancement of international liquidity and policy responses in the OECD countries which checked inflationary pressures mainly through the restriction of money supply. The result was severe worldwide recession, with real interest rates climbing to the highest levels seen in the post-war era. The consequent fall of commodity prices joined the increase in the price of oil to further depress the terms of trade of the oil-importing countries to their lowest levels since the 1930s.

The attitude of commercial banks and national policy responses to these events aggravated the underlying situation of most Latin American countries. Some banks, overflowing with liquidity, tried once again to recycle their petrodollars to developing countries. Just as in the earlier petro-crisis of 1973/1974, most oil-importing Latin American countries interpreted their difficulties as a liquidity crisis, resorting to further indebtedness to overcome what was considered as a transitory restriction. ${ }^{26}$ Oil-exporting countries also took advantage of the permissive supply of credit to become further indebted, but on the contrary assumption that their export-price bonanza had a permanent basis. (Bianchi, Devlin and Ramos, 1987).

By 1982 the stage was set for a major regional crisis. Most countries were already highly indebted (Argentina, Brazil, Costa rica, Chile and Mexico, by well beyond three times the value of their exports) and were burdened with interest payments exceeding the critical threshold of $20 \%$ of their exports (in fact, they amounted to more than $40 \%$ and even $50 \%$ in the cases indicated above). ${ }^{27}$ On the other hand, the world recession and OECD monetary policy kept export growth --even of the oil-exporting countries-- well below the level of nominal interest rates (Cline, 1984). What has been less noted, but seems nonetheless to be crucial, is the fact that debtor governments, responsible for at least a third and often more than half of the total external debt outstanding (see table 4), were already facing interest payments to the tune of $7 \%$ to $10 \%$, or even $17 \%$ (Mexico and Ecuador) or $40 \%$ (Costa Rica) of their current public revenues (see table 5). ${ }^{28}$ Moreover, public indebtedness, fueled by mounting fiscal deficits, was growing faster than public revenues.

As mentioned earlier, the financial stress in the region turned into a full-blown crisis in 1982, when the Mexican moratorium unleashed panic across the market, and even the most responsible borrowers came to be viewed by bankers as still further examples of half-collapsed economies in a "bad neighborhood". New credit flows came to a virtual halt, and by early 1983, with the cut-off of the rollover process, almost every Latin American debtor with significant exposure with the banks faced a situation of de facto default (ECLAC, 1990a). 
As a result, the finance of Latin American development underwent a major structural change. The net inflow of funds suddenly reversed, as a consequence of the fact that the previously sustained supply of credit turned into an effective demand for repayment. Countries with a roll-over ratio well below one in 1980-1981, indicating that their debt service had been amply financed by new disbursements (Argentina, Chile or Ecuador), or around one (Bolivia, Brazil or Costa Rica), suffered sharp jumps in their ratios, as new finance fell far short of covering debt service accruals (see table 6).

Moreover, the payment crisis had been anticipated by economic agents, causing unregistered net outflows of private capital; during the 1981-1982 period the outflow amounted to US\$ 45 billion, or more than $20 \%$ of the region's exports. When, in 1983 the net credit transfer to the region also became negative, as a consequence of the breakdown of the rollover process, the countries of the region began transferring outward around US\$30 billion annually, or $25 \%$ to $30 \%$ of regional exports (ECLAC, 1990a).

During the crisis, many countries saw their international reserves dwindle to less than three months of imports and some (e.g. Mexico and Uruguay) to less than a month (see table 7).

In such a predicament, the Latin American countries' adjustment of their external accounts was forced and painfully swift. (Insofar as interest payments were considered sacrosanct, the trade balance must forcibly adjust itself.) Moreover, since export growth was bounded --in the short and medium term-- by productive and marketing capacities as well as the vagaries of world commodity markets, adjustment had to be based primarily on the contraction of imports and the resulting paralyzation of economic growth.

Actually, the region as a whole produced trade surpluses of more than US\$30 billion a year in the 1983-1985 period, curtailing its imports to less than US\$ 60 billion, compared with US $\$ 90$ billion in 1980 . Many countries reduced their imports to around $80 \%$ of exports, while for some (Argentina, Brazil, Ecuador, Mexico and Venezuela) imports shrank to less than two-thirds of exports. Only Costa Rica was able to maintain its trade balance more or less even, while Colombia managed a gradual and sustainable adjustment (see table 8).

Such massive external adjustment based on the compression of imports was, for some countries, clearly untenable in the longer run. But it was on the fiscal front --which, unlike the external sector, was not subject to automatic adjustment-- where many of them began to flounder. At the outbreak of the crisis, public external debt in some countries (Argentina, Ecuador, Mexico and Peru) was significantly greater than current public revenues; in Costa Rica and Bolivia, it was 3.7 times and 7.9 times current revenues, respectively (see table 9). During the crisis, public external indebtedness rapidly increased, driven both by agreed capitalizations of interest and by the forced public assumption of a large part of the private external debt which had originally been contracted without a government guarantee. ${ }^{29}$ By 1985 , only in Venezuela was public external debt roughly equivalent to fiscal revenues. In Brazil and Colombia, it was $40 \%$ higher than revenues and most countries had a public external debt/fiscal revenues ratio 
close to or higher than 2; in Peru, this ratio was higher than 3, and in Bolivia close to 6 (see table 9).

Accrued interest on public debt outstanding climbed sharply during the crisis. In 1980 it had represented moderate proportions of current fiscal revenues: little more than $2 \%$ in Argentina, between $4 \%$ and $10 \%$ in most other countries and $13 \%$ in Peru, the outlier being $20 \%$ in Bolivia. By 1982 in some countries this proportion had doubled or tripled. In 1985 accrued interest already amounted to $11 \%$ of current revenues in Brazil and Colombia, between 15 and $20 \%$ in Argentina, Chile, Ecuador, Mexico and Uruguay, 22\% in Peru and $39 \%$ in Bolivia (see table 5). ${ }^{30}$

Thus, interest accrued on external public debt became a major force driving public sector deficits. Excluding Costa Rica and Venezuela --which had fiscal surpluses--, by 1985 interest accruals represented at least between a half and two-thirds of the level of the countries' public sector deficits, and in some cases (Bolivia, Ecuador, Chile and Uruguay) had become greater than their shrinking public deficits (see table 10).

Aggravating this increased burden, most Latin American states were faced between 1982 and 1984 with the consequences of their creditors' decision to cut off the roll-over finance of public debt service. Brazil and Peru delayed the reversal of the flow of funds until 1985, and Colombia was able to maintain a favourable roll-over ratio until 1987. Chile's Government benefitted from a positive flow of funds during the 1982-1985 period (see table 11).

These processes involved massive turnarounds in the net flow of resources between governments and their external creditors.

Before the crisis, many governments had received a net external transfer amounting on average to $6 \%-8 \%$ of their current revenues. During the crisis years, the net transfer of external resources became negative for most Latin American governments, representing significant proportions of their revenues. This amounted to a turnaround of resources equivalent to $9 \%$ of current public revenues for Brazil, 12\% for Ecuador and Venezuela, 14\% for Argentina, $17 \%$ for Mexico and Uruguay, and $18 \%$ for Colombia (since 1987). On the other hand, the Governments of Chile and Peru bore negative net external transfers in the years just before the crisis, which became significantly positive in 1982/1984, only to turn negative again since 1985 (see table 12).

In such circumstances, fundamental macroeconomic stability, coupled with external debt compliance, required that the countries not only produce a trade surplus equivalent to the transfer of financial resources abroad, but also that the public sector obtain a parallel primary (that is, prior to interest payments) surplus that would allow it to secure the resources for financing the public transfer. As has been noted elsewhere (ECLAC, 1989), in countries where the public sector owns the main export industries, there is a direct connection between the economy's capacity to sustain a net transfer of resources abroad and the public sector's financing capacity: the external and fiscal balances tend to work in tandem. On the other hand, in countries whose main exports are owned by the private sector, even when the trade surplus may 
provide the basis for transferring resources abroad, the debtor government has to raise domestically the resources to cover its greater expenditure.

The degree of success in attaining this goal has been heavily determined by two factors: the fiscal situation prior to the external shocks and the repercussions of the external adjustment on the public budget. (Fanelli, Frenkel and Rozenwurcel, 1990). These, in turn, varied from one country to another, according to the degree of public indebtedness, the public balance of payments (structurally different, as noted above, for those governments that own exportable resources and for those that do not), and the degree to which creditors maintained flows of finance to the public sector during the crisis.

Among the "natural resources owners", the Government of Chile had already attained a primary fiscal surplus before the outbreak of the crisis. The effects of the shocks of $1983 / 1984$ on the public budget and external accounts were mollified by ample net external finance to the government. From 1985 onward Chile was able to gradually restore its fiscal surplus by a systematic adjustment, supported by continuing external finance. Venezuela also entered the crisis from a fiscal surplus; after a slump in 1982, the government was able to maintain, more often than not, a surplus position closely linked to the fluctuations of its oil revenues.

Mexico, Bolivia, Ecuador and Peru entered the crisis with sizable fiscal deficits. Mexico underwent a staggering fiscal adjustment, without great external support, that turned adrift in 1986. As mentioned earlier, a debt rescheduling in that year, at the brink of a formal moratorium, brought the government new external finance in 1987. The authorities started a new and successful fiscal adjustment process in 1988. Later the external financial squeeze was eased as a consequence of a turnaround of confidence in Mexico and a renewal of autonomous capital inflows, which were in turn greatly helped along by the denationalization of the banks, the expectations of a free trade zone with the United States and the symbolic effects of being the first customer for a Brady-style debt reduction exercise. ${ }^{31}$

Ecuador also underwent a significant fiscal adjustment in 1984-1985 that was eroded after the 1985 drop in oil prices and disappeared altogether in 1987, after an earthquake's damage of export capacity affected both the external and fiscal balances and led to the country's moratorium.

Bolivia was able to postpone a formal moratorium until 1984, when accumulating internal imbalances, an unsustainable public external debt burden and the collapse of export prices led to hyperinflation and economic and fiscal collapse. A selective moratorium, coupled with a draconian fiscal adjustment beginning in 1985, followed later by a supportive attitude on the part of official creditors and the 1988 buy-back of half of the commercial bank debt, allowed the country to maintain relative macroeconomic stability (Cariaga, 1992).

Peru's pre-crisis situation of fiscal deficit improved during 1984-1985, while external adjustment took place and the government continued to receive net external finance, in the context of a quiet moratorium. The political decision of a new government to formalize and 
radicalize the moratorium precluded new external finance for the public sector. However, macroeconomic stability was not seriously imperiled until domestic policy-induced fiscal and external imbalances pushed the economy into hyperinflation.

Although not a "natural resources owner", Colombia's public sector has had direct access to foreign exchange through the coffee (compensatory) fund and, more recently, through its increasing exports of oil and coal. In 1981-1983 both the trade and fiscal deficits were sizable, but public external debt and its service were kept at relatively low levels. Sound macroeconomic management, and continuing net external finance for the public sector (at least until 1986), allowed the country to carry out gradual external and fiscal adjustments.

The predicament of other "natural resources non-owner" governments has been quite different. In Argentina, the sizable pre-crisis fiscal deficit widened even more as a consequence of the assumption by the public sector of the private external debt and the rise in international interest rates. Although considerable trade surpluses were obtained in 1982-1985, due to a rapid external adjustment, the government was unable to either raise the tax burden or reduce public spending to the degree needed to service the growing public debt. After the strategic moratorium of 1983/1984 was abandoned, the Austral stabilization programme managed to reduce the fiscal deficit and obtain some fresh external money. When the situation on both fronts deteriorated, along with expectations and inflationary pressures, a de facto moratorium followed in 1988 (Machinea and Sommer, 1992).

Brazil sorted out the 1982 payments crisis and bore the burden of its external debt by obtaining huge trade surpluses. Significant primary fiscal surpluses until 1986 allowed the government to manage the growing burden of interest payments on the public budget. However, the reversal in 1985 of net external finance to the public sector further strained an already deteriorating fiscal balance. In such circumstances, the gaping deficit --now also fueled by the mounting burden of interest on the domestic public debt-- and the eroding trade surplus were behind the moratorium of 1987. As mentioned earlier, although the moratorium was lifted the following year, the deteriorating fiscal situation amid accelerating inflation led to another moratorium in 1989.

The fiscal situation in Uruguay had been relatively stable before the crisis and was gradually brought under control again, with the country achieving even primary surpluses beginning in 1985 . The permanent trade surplus allowed for the external transfer, but the Uruguayan Government's difficulty in capturing domestically the corresponding resources has been evident in the significant inflationary tax that it has collected. In such circumstances, the strategy of avoiding a moratorium is better explained by the considerable proportion of dollar deposits in the financial system and the government's goal of maintaining its status as a regional financial center.

Costa Rica had an almost even balance of trade, a solid primary fiscal surplus and abundant net external financing for its public sector. Its moratorium seems to be explained by the political requisites of achieving needed adjustment without significantly damaging the level of economic activity. 
This analysis suggests that the regional drama of muddling through a protracted debt problem and the eventual emergence of moratoria is better understood as a story of debtor governmements amid a systemic financial crisis than as a story of debror connontries trying to adjust to a new international economic situation. True, the external constraint was at the forefront of the payments crisis, and the export performance of each country continued to be the essential stand from which to approach it. But servicing of the debt chiefly rested upon the government's shoulders, ${ }^{32}$ thereby aggravating the fiscal deficit and the requirements for fiscal adjustment.

At least four consequences stem from this situation. First, credit rationing to the countries has been, in fact, rationing of the governments' necessary rollover funds; hence, the role of multilateral or bilateral official finance has been much more strategic than their amounts would suggest. (See O'Connell, 1992.) Second, underlying fiscal balances, after interest accrued on the public external debt, have been decisive in permitting countries to successfully muddle through the debt problem without resorting to moratoria. Third, the capacity of the government -based on its ownership of exports-- to collect export earnings without domestic transfers and apply them to servicing the debt has also been decisive. Fourth, prospects for fresh finance, coupled with the political tolerance for IMF-style adjustments and lost output also entered into the moratorium calculation. Finally, strategic considerations in renegotiation of the debt could also be an important factor.

\section{THE ADMINISTRATION OF THE MORATORIUM}

A moratorium must be administered in some way. One would expect the sophistication of that administration to vary according to the circumstances. A planned moratorium should have a more sophisticated administration than one that emerges suddenly due to an unexpected payments burden and/or a collapse of economic policy. The more conflictive a moratorium, the more complicated its management. One also would expect that the longer the moratorium is held in place, the more refined its management will become. All these observations are more or less borne out by the experience of the countries.

\section{A. The tone of the moratorium}

The vast majority of moratoria in Latin America have been quiet and discreet in nature. This has even characterized the strategy of revolutionary regimes such as those of Cuba and Sandinista Nicaragua. ${ }^{33}$

The most conflictive strategy was adopted by the Garcia government in Peru. As mentioned earlier, it inherited a silent moratorium on the service of debt to the banks, governments and suppliers. During his Presidential campaign, García had warned that his country could not have its growth compromised by the foreign debt and the recessive policies of the IMF. Even so, he informally had signaled to the banks that he was willing to renegotiate 
the debt (Figueroa, 1992). Thus it was a surprise to the financial community when the President, upon assuming power in July 1985, publicly announced that over the next 12 months his country would unilaterally limit debt service on medium-term public debt to $10 \%$ of the country's exports. Thereafter, the government's rhetoric hardened and meetings with creditors became sporadic and conflictive. Hopes of a settlement evaporated when the government announced that the $10 \%$ formula would be renewed in July 1986 and would include private sector medium-term debt.

Brazil's two moratoria with the banks never approached the high profile witnessed in Peru. Nevertheless, they did involve obvious and direct challenges to the official debt strategy. The first phase of the 1987 moratorium, managed by Minister Funaro, was rather aggressive in tone and did not articulate its objectives very clearly, or offer the banks many alternatives. ${ }^{34}$ The administration of the moratorium's second phase, which began in May of that year under the leadership of a new Minister, Mr. Bresser Pereira, was much more constructive; nevertheless, the authorities also openly challenged the standard rescheduling/new money formula of the Baker Plan. The team insisted that an agreement must respect Brazil's capacity to pay (2.5\% of GDP) and it eventually proposed an obligatory exchange of about one-half of the country's US $\$ 70$ billion bank debt for bonds with a discount of $30 \%-40 \%$. Given the banks' strong resistance to the scheme, there also was some consideration of the possibility of imposing it unilaterally (de Freitas, 1992). However, the proposal and the moratorium lost momentum in September, when the Minister was personally informed by the United States Treasury Secretary Baker that the Brazilian payment plan was a "non-starter".

By late September the country had reached an understanding with the banks to eliminate arrears in an interim agreement that would be a prelude to an IMF programme and a debt restructuring package. Nevertheless, at the end of the year, the authorities began to reassess their bargaining position and reconsidered the possibility of imposing a unilateral exchange of debt for bonds (de Freitas, 1992). However, as events materialized, Minister Bresser Pereira resigned in December and his successor, Mailson da Nobrega, quietly led Brazil to a rather conventional restructuring accord in June 1988.

Ironically, Brazil's second moratorium was initiated by Mailson da Nobrega, the same man who ended the first moratorium. Moreover, the second one began as quietly as the first had ended. The government's liquidity position had been deteriorating as the private banks and IMF were withholding disbursements of new loans on account of the country's inability to comply with the Fund's conditionality. By July of 1989 the government began to fall behind in some payments. The Minister made it clear that if an interim financing agreement was not reached with the IMF by September, when some US $\$ 2$ billion of payments to the banks came due, he would be forced to suspend debt service in order to save international reserves. The expectations of a moratorium became so well entrenched by September that, when the interest payments were suspended, it was practically a non-event. The problem was passed onto a new government, which would be elected by the end of the year. 
In March of 1990, the new Collor administration assumed a hard bargaining position sased on the public sector's capacity to pay. The banks insisted on payment of arrears as a condition for a global debt agreement. The government, on the other hand, made it clear that it would not make any payment prior to agreeing on a comprehensive restructuring accord which included a large reduction in interest payments. In October, the government presented a proposal to convert the stock of debt into bonds and decentralize negotiations of private sector debt. The proposal was quite sni gemeris and largely outside of the framework of the Brady Plan, e.g., some of the bonds had an unprecedented maturity of 45 years; there was no provision at all for collateral and the private sector debt would be left to market forces. The banks rejected the idea outright and also were upset by Brazil's decision to break with tradition and not reimburse the travel expenses of the banks' Advisory Committee (The Ecconomist, 1990). ${ }^{35}$ Brazil also was rebuffed when it informally proposed that a similar scheme should apply for Paris Club debt. From that point on the moratorium began to peter out as the economic team became more isolated and pressure increased on Brazil to conform to the bankers' demands.

It already has been mentioned that Argentina's first moratorium had its conflictive moments, but these were interspersed with conciliatory gestures, such as when the government accepted a bridge loan to partially pay interest arrears and thereby avoid a downgrading of the United States bankers' debt (Machinea and Sommer, 1992). As already mentioned, in 1984 the Siles Zuazo government in Bolivia attempted to formalize a payments scheme for its moratorium by limiting payments to $25 \%$ of exports. It also apparently lobbied for a debtors' cartel. Finally, Costa Rica, generally a master of subtle debt negotiations, unwittingly raised the profile and conflict around its first moratorium by initiating it in August 1981 with a formal governmental decree (Rodríguez, 1992).

Why would a country pursue a strategy of open conflict with its creditors? Domestic politics clearly played a role in Peru, where the debt and the IMF were used as negative foils in a populist domestic strategy. The García government also apparently had ambitions to become the leader of a regional strategy on the foreign debt. Domestic politics also played a role in the tougher phases of the Brazilian moratoria. The first phase of the 1987 moratorium could have partially served to divert attention away from the collapse of the domestic economic program. ${ }^{36}$ In the second phase, the economic team was also apparently motivated by the opinion that its ideas for dealing with the debt overhang were so rational that they would ultimately be acceptable to the governments of the creditor banks (de Freitas, 1992). As for Argentina, its tough strategy in the first moratorium may have been partly related to an anticipation of tolerance in official circles on account of the tremendous goodwill that the new democratic government enjoyed in the creditor countries (Machinea and Sommer, 1992; Frohmann, 1986 and 1989). 


\section{B. The queue for payments}

A moratorium is rarely applied to all creditors; some selectivity usually comes into play. With regard to the loans by commercial banks, some banking analysts had argued in the 1970s that "the full and prompt servicing of debt to the lender has the highest priority in the usage of foreign exchange resources of a country" and would in effect be comparable in importance to the import of petroleum, food and pharmaceuticals (Friedman, 1980). That optimism proved incorrect in the case of Latin America, where the principal creditor was the commercial banks. Indeed, banks have usually been the primary target of moratoria in the region. The next most frequent target has been selective restrictions on Paris Club countries. (See Abbate, Lawrence and Miroux, 1992.) Only the most desperate cases have included the multilateral lenders in their moratorium (O'Connell, 1992) (see table 13).

In restricting payments to the banks, countries have usually excluded short-term debt so as to dissuade lenders from cutting this credit, which is important for day-to-day external trade. Peru also exempted post-July 1985 debt to encourage new lending. Private sector unguaranteed bank debt has usually been included either formally, as in the first Brazilian moratorium and the Peruvian exercise (beginning in July of 1986 ),${ }^{37}$ or informally due to the unavailability of foreign exchange at the Central Bank, or the existence of exchange rate guarantees of one type or another. But there are cases where private sector debt has been unaffected, as in the case of Argentina, Ecuador and Brazil in the latter part of its second moratorium.

During a moratorium the countries have frequently made symbolic payments at one time or another on the restricted debt. More recently there has been a tendency to consistently service part of the bank debt according to some notion of the capacity to pay. For instance, in 19871988 Costa Rica followed a policy of paying about 30\% of its interest due to the banks (Rodríguez,1992). As already mentioned, Ecuador and Argentina (during the second moratorium) formalized regular partial payments. And in its second moratorium, Brazil began to unilaterally service $30 \%$ of its interest due. Unfortunately, what began to appear as an encouraging pattern under the Brady Plan for orienting debt service to the capacity to pay, has been called into question by the already mentioned reversal of IMF policy in Brazil.

The restriction of debt service to Paris Club countries usually has been simultaneous with, or lagged behind, the restriction on bank debt. However, Costa Rica's third moratorium, as well as those emerging in Paraguay and the Dominican Republic, were started by restrictions on the Club's obligations (see table 13). Paris Club governments have often unwittingly made themselves targets by permitting their export credit agencies to restrict new loans even to debtor governments completing IMF condionality and reschedulings. The excessive rigidity of the Club's rescheduling techniques has also been a problem. (See Abbate, Lawrence and Miroux, 1992.) Available information suggests that payments to creditor countries have usually been restricted according to political considerations, the degree of tolerance of the creditor governments, and whether there were prospects of a positive transfer of resources. For example, Peru and Argentina selectively resumed payments on German debt in order to be eligible for a new project loan (Figueroa, 1992; Machinea and Sommer, 1992). Costa Rica also stayed current 
on United States Government debt because of the potentially large amount of funding available from that country (Rodríguez, 1992).

The only countries to have seriously restricted multilateral debt service are Peru, Nicaragua, Panama, Guatemala and Honduras (O'Connell, 1992). ${ }^{38}$ The restriction invariably has coincided with a fall-off in new disbursements, usually related to an inability to comply with the multilateral instifution's conditionality. Nevertheless, most countries have continued to service multilateral debt even in the face of problems with conditionality and the consequent negative transfers of resources. This reflected the perceived political importance of avoiding conflicts on this front.

Finally, only two countries introduced a formal ceiling on the total service of debt by linking payments to a percentage of exports: as mentioned earlier, in 1984 the Siles Zuazo government used a formula of $25 \%$ and the García administration applied a $10 \%$ rule. Under these formulas practically all the banks and a large number of the Paris Club governments were excluded from debt service. On the other hand, multilaterals were given priority access to foreign exchange. However, in Peru, the IMF --with which there were no prospects of a program-- was immediately affected by the $10 \%$ formula, leading in August 1986 to a formal declaration of ineligibility by that institution. In early 1987, Peru also stopped payments to the World Bank. And in mid-1988 the restriction was applied to the IDB (Figueroa, 1992).

\section{Defensive measures}

The conventional view is that a moratorium will risk devastating retaliation from disgruntled creditors. At risk is everything from loss of short-term lines of credit to the attachment of reserves, exports, airplanes and other tangible assets of a government ${ }^{39}$ Countries therefore might be expected to protect themselves from such risk, especially in cases of a prolonged moratorium, or one which is surrounded by real or potential conflict.

\section{International reserves}

Reserves and other deposits of the defaulting government are vulnerable to legal attachment. A country is particularly vulnerable in the United States, where a dangerous tactic called a "set-off" is commonly used. In effect, it allows a bank to recover an overdue payment by directly attaching a deposit of the relevant debtor. Moreover, this can be done without any prior court approval. ${ }^{40}$ While the international reserves of a country should enjoy sovereign immunity, in the post-war era the legal interpretation of this concept has narrowed to such a degree that there is considerable risk, especially in the United States, of a country's official assets being treated as commercial in nature (Biggs, 1992).

A strategy observed in Argentina, Ecuador, Costa Rica, Brazil and Peru was the gradual withdrawal of reserves from commercial banks that were considered to be "unsafe". In all these 
cases, United States banks, which tended to have a more aggressive attitude, and of course access to the set-off, were considered unreliable. Peru and Ecuador also tried to avoid any banks with which they had a debt, and small banks, which traditionally can be cantankerous.

A common safe haven for all these countries was the Bank for International Settlements (BIS) in Basle. However, Peru found that this Bank succumbed to outside pressure and severely restricted the amount of deposits that it could place there. The authorities explored the possibility of using the Andean Reserve Fund (ARF) in Bogota as a depository, but, in the end, the country's lawyers deemed it unsafe. (Subsequently, the ARF developed a safe CD). Thus, Peru deposited in numbered accounts of banks in Europe and in subsidiaries at financial centers. With some difficulty, it often secured formal comfort letters from the bank which pledged that it would not embargo deposits (Figueroa, 1992). Ecuador also pursued a similar strategy. Peru furthermore converted part of its reserves into gold, which it flew back to Lima.

Argentina considered the United States Federal Reserve (FED) to be a safe haven during its second moratorium (Machinea and Sommer, 1992). On the other hand, Brazil, which had used the FED as a safe haven during the uncertain rescheduling negotiations of 1982-1983, considered this institution unsafe during the 1987 moratorium (de Freitas, 1992). Meanwhile, throughout the $1980 \mathrm{~s}$, Costa Rica also used as a safe haven the Banco Latinoamericano de Exportaciones in Panama, as well as a subsidiary of a consortium of government banks, also located in Panama (Rodríguez, 1992).

In preparation for the 1987 moratorium, Brazil carefully withdrew its deposits from the United States via a circuitous route. However, it needed to have a clearing institution in that country because of its large-scale export trade in dollars. The authorities found a large bank which promised not to attach any deposits in return for the exclusive business of clearing accounts due. However, the bank refused to offer a comfort letter and instead the two parties relied on a gentlemen's agreement (De Freitas, 1992).

Costa Rica also encountered a large bank which offered a plan in which the country could overdraw on an account and cancel the negative balance at the end of the day. In this way the country enjoyed a degree of liquidity without having any assets in attachable deposits (Rodríguez, 1992).

In addition to withdrawing official reserves, Peru and Brazil also warned all government entities to avoid unsafe depository institutions, and especially those located in the United States. On the other hand, in 1988-1989, Argentina --which had not declared a formal moratorium-- did not take any special precautionary measures in this regard (Machinea and Sommer, 1992). 


\section{Short-term lines of credit}

Commercial lines of credit are particularly vulnerable to reduction, because they are short-term and subject to regular renewal. Indeed, information on Bolivia, Costa Rica, Argentina, Peru, Ecuador, and Brazil indicates that all these countries were subject to pressure along these lines during their respective moratoria. There were interesting differences in the way the countries dealt with the problem.

Bolivia's moratorium in the early 1980 s emerged gradually and in uncertain fashion. By early 1983, the banks were aggressively eliminating credit lines to the private and public sectors; moreover, this happened so quickly, and the authorities had so many other problems to deal with, that few countervailing measures emerged (Cariaga, 1992). Ecuador also did not take any special measures to guard against loss of short-term credit; it simply concentrated business in the handful of banks and export credit agencies that remained willing to do business with the country (Yepez, 1992). On the other hand, Costa Rica actively shopped around to replace eliminated lines with new ones. In the early and mid-1980s it found that European banks -especially Spanish ones-- and United States banks without exposure in Costa Rica, could substitute for the retreating creditors. When the European banks became a difficult source of supply in 1987, the country found that their United States competitors were more receptive to the extension of short-term credit. Costa Rica also relied on continued cover by the United States EXIMBANK, which insured some commercial lines. Finally, it deployed foreign exchange denominated capital of its State banks to open new lines of credit (Rodríguez, 1992).

During its second conciliatory moratorium, Argentina largely relied on the banks to respect the "captive" lines of credit, which were negotiated with them in prior rescheduling agreements, ${ }^{41}$ and the use of foreign exchange controls in the official sector (Machinea and Sommer, 1992). Peru also tried to make the banks respect the captive lines from earlier reschedulings. It substituted lost lines by shopping around, especially at banks without exposure in Peru, and frequently by collateralizing new lines with foreign exchange reserves, including gold. The country also placed a minimum amortization period on import financing to induce foreign firms to bring in their own capital (Figueroa, 1992).

The most sophisticated strategy was applied in Brazil. During the 1987 moratorium, the Central Bank froze the country's captive lines of credit. In effect, banks were not allowed to reduce that credit; they could only recirculate it upon maturity to new customers within the country and charge the prevailing commercial rate. On the other hand, voluntary lines, i.e., those in addition to the captive lines, were left to the forces of supply and demand. When the banks shortened export financing excessively, the government countered by opening up special lines of credit out of its own resources. (A more drastic contingency plan for dealing with problems in this area never had to be drawn upon). Meanwhile, in the second Brazilian moratorium of 1989-1991, the government chose not to freeze captive lines. An attempt was made to substitute lost credit by redeployment of certain foreign exchange resources in the domestic banking system and by more intensive use of domestic savings (de Freitas, 1992). 
Finally, it should be noted that all of the above-mentioned countries used prices to clear markets. This usually involved some rise in the price of credit, due to collateral or higher spreads. One extreme case was Argentina, in 1989. With the economy on the edge of a hyperinflation, the exchange market collapsed and spreads rose to 4-5 points over LIBOR (Machinea and Sommer, 1992).

\section{Other measures}

To avoid retaliation, countries often tried to maintain a dialogue and cordial relations with their multilateral creditors --especially the IMF-- and the key OECD governments, especially the United States; Costa Rica pursued this course of action very effectively after 1982. So did Ecuador, Bolivia, and Argentina. When law suits emerged, all the countries tried to deal with them discreetly, and as a special case, in order to reduce bad publicity. In the second moratorium, Argentina avoided cash settlements to recalcitrant lenders in order not to provide incentives to other banks (Machinea and Sommer, 1992).

National consensus building on the issue of moratorium was also another defensive measure. In Costa Rica of ficials purposely organized seminars, workshops, and TV and radio programs to inform businessmen and the public at large of the country's problem of overindebtedness (Rodríguez, 1992). Meanwhile, President García's charisma and political campaign mobilized a latent consensus in crisis-ridden and IMF-weary Peru. Bolivia's formal pact between the government and the country's labor union in 1984 is suggestive of some type of consensus building there. Meanwhile, Paz Estenssoro's government built a consensus around its stabilization program, which subordinated the payment on part of the debt to the need to close internal and external macroeconomic gaps (Cariaga, 1992). As for Ecuador, the unexpected sharp fall of the price of petroleum, coupled with an earthquake, produced a type of national consensus there about the country's inability to service debt. On the other hand, Brazil's 1987 moratorium appeared to lack such a consensus (de Freitas, 1992). ${ }^{42}$

\section{THE EFFECTIVENESS OF THE MORATORIUM STRATEGY}

The effects of a moratorium can be transmitted through an extremely large number of channels. This, coupled with the need to introduce broad counterfactuals, makes a precise evaluation of the impact of a moratorium somewhat problematical. In any event, a comprehensive evaluation is beyond the scope of this overview. What we will do, however, is draw from some of the more obvious aspects of the experience, to make tentative observations about the efficacy of a moratorium as an instrument of economic and political policy, and as a platform for renegotiating the debt. 


\section{A. Economic performance}

Perhaps the bottom-line concern is how well the economy performed during its moratorium in payments. Arrears are conventionally not considered to be the way to good economic performance. And, indeed, the vast majority of countries in moratorium during the $1980 \mathrm{~s}$ performed very poorly. It can be observed that the moratorium countries are crowded in the right-hand comer of Table 14, which expresses a situation of low or sporadic growth combined with important inflationary problems. The only moratorium countries that have displayed growth in a controlled inflationary setting are Costa $\mathbb{R i c a}$, and, more recently, Paraguay. Meanwhile, although Bolivia did not achieve much growth during its long moratorium, in 1985 the $\mathrm{Paz}$ Estenssoro administration did undertake a world-acclaimed stabilization programme which rid the country of a hyperinflation. Cuba and Honduras also can at least point to price stability during their periods of moratorium. Finally, Guatemala has recently registered some growth, but with considerable inflation.

Based on our simplified proxies of economic performance, only five countries had something positive to show during their respective moratoria. This experience does not provide much encouragement for a temporary arrears-based economic strategy.

On the other hand, the problem debtor countries that continued to service their debt contractually also had a mixed experience. Chile is the only country which registered a long period of growth with relative price stability. Mexico has more recently joined the group (and Venezuela's prospects for the 1990s have improved) (see table 14) ${ }^{43}$ All three countries, but above all Mexico, have also gained renewed access to international capital markets (West, 1991).

Chile was a "model" debtor during the 1980s. Mexico was too, although on more than one occasion it wielded a tough threat of default to make the bankers accede to a more favourable rescheduling agreement. Both nations are on the so-called Washington Consensus' list of countries that seriously pursued policy reform in the 1980s (Williamson, 1990). The two borrowers were almost always on good terms with the IMF. Both nations had political systems which gave the economic authorities considerably more degrees of freedom than are found in most other countries of the region. ${ }^{44}$ The countries' governments are also owners of important natural resource exports.

Clearly, the two most distinguished moratorium cases are Costa Rica and Bolivia. Both countries were in arrears with one or more of their principal creditors for most of the 1980s. Although Costa Rica and Bolivia took firm stances on their limited capacity to pay, they --from 1982 and 1985, respectively-- discreetly and constructively engaged their creditors and worked hard to arrive at settlements. Both countries underwent adjustment and stabilization programs that gained international respect and put them on the Washington Consensus' list of serious policy reformers (Williamson, 1990). At the same time, both borrowers eventually undertook IMF adjustment programs (Khan, 1990). Costa Rica is an established democracy, while Bolivia is what has been termed a transitional democracy (Kaufman and Stallings, 1989). 
Paraguay, the other moratorium country in the upper left hand corner of Table 14, has had a growing payments restriction throughout most of the 1980s. In recent years it has pursued policy reform and is a newcomer to the Washington Consensus' list (Williamson, 1990). It has not had a programme with the IMF. The country became a transitional democracy in 1989.

As for Cuba its achievement of price stability is basically attributable to a long-reigning system of rigid controls and a stable exchange rate made possible by special bilateral aid flows. Honduras benefitted from price controls and considerable bilateral assistance related to the conflict in Central America. Finally, Guatemala's growth coincided with an overall improvement in economic policy reform in 1986-1988 under its new democratic regime; however, thereafter the country has backtracked substantially. It has not had a programme with the Fund.

Among the best economic performers in Table 14, there are those countries which operated in a moratorium setting and those that did not. The countries exhibit very different socio-economic characteristics, but where there is some overlap is in their respectable economic programs. Thus, as a first approximation, it might be suggested that the economic benefits of a moratorium will be limited if the latter is not an integral part of a coherent and sustainable economic adjustment program. The link to economic policy is further strengthened when one considers that in all the cases the payments restrictions themselves were generally well administered.

\section{B. The transfer of resources}

As can be seen in Table 15, the moratorium countries which have received the most attention in this paper all significantly reduced their credit-related outward transfer of resources during periods of restricted debt-service payments. The most radical reduction was in Peru, where the negative credit-related transfer fell sharply and actually turned positive in 1987-1988. The mildest restriction on the credit-related transfer is observed in Costa Rica. The more favourable credit-related transfers, moreover, were usually paralleled by an improvement in the overall transfer. ${ }^{45}$

The moratoria also were associated with reduced internal restrictions. In effect, available information indicates that during periods of moratoria the governments generally were able to sharply reduce interest payments on the external public debt as a percentage of public revenue (see table 5).

While the moratoria were generally associated with lower internal and external transfers, it must also be asked whether a similar or better result could have been achieved by participation in the official debt program, which in principle opened up access to new medium-term credit, as well as the renewal of captive short-term lines. Indeed, by using this logic, a postmortem analysis of the 1987 Brazilian moratorium, prepared by the country's Central Bank, concluded that there was a net cash loss to the country of US $\$ 700$ million (de Freitas, 1992). However, studies like this tend to beg the central issue: in all the countries, what led to a moratorium in the first place was an inability to access predictable and adequate new financing within the 
framework of the official debt strategy. The first bottleneck, in nearly every case, was an inability to comply with tight $\mathbb{M M F}$ quarterly targets, which in tum paralyzed multilateral disbursements and also any that had been committed by the commercial banks and other creditors. The second obstacle was the great reluctance of the banks and official export credit agencies to commit themselves to adequate, sustained and predictable new lending in the first place. In effect, in these circumstances a moratorium often was not so much a choice as a forced response to the increasingly weak refinancing mechanisms in the international debt strategy.

\section{The effectiveness of defensive measures}

The moratoria never produced massive retaliation by the creditors. Problems of course arose on different fronts, but there usually were reasonably effective tools for dealing with them. On the other hand, the countries' defenses were the weakest at times when the domestic economic programme fell into disarray. Indeed, as soon as a domestic economic programme lost its way, formerly effective defensive measures became much less effective. Moreover, capital flight would reappear as a serious problem, as was the case in Argentina and Peru (Machinea and Sommer, 1992 and Figueroa, 1992).

All the countries were invariably harassed by sporadic lawsuits and set-offs that required quiet bilateral negotiations and legal defenses. A Costa Rican defense early on in the crisis initially established a precedent which --if it had been sustained-- would have dramatically improved the entire character of the international management of the debt crisis. In effect, the country found itself confronting a battery of legal proceedings after a severe economic crisis caused the Carazo government to decree a debt moratorium in 1981. However, all but one of the suits were quietly settled by bilateral negotiations and Costa Rica's eventual entry into the first round of reschedulings. The remaining holdout, a small United States bank which had participated in a syndicated loan organized by Allied Bank, refused to settle and pursued the matter in United States courts.

The case is legally complicated, ${ }^{46}$ but in essence the Costa Rican defence initially prevailed: the court agreed that Costa Rican banks could not service their foreign debt because it would have violated the law of a sovereign state. An appeal by the United States bank also failed. On this occasion, the court found that Costa Rica's debt programme was consistent with United States foreign policy; to wit, the restriction on payments was similar to a Chapter 11 bankruptcy, in which the country temporarily restricted payments as a prelude to the debt reschedulings which the United States Government supported. However, the bankruptcy analogy created great concern in United States financial and Governmental circles. The case was taken to a rare appeal in Washington D.C. and this time the bank carried a letter of support from the executive branch of the United States Government. In a reversal that appeared somewhat arbitrary, the court ruled against Costa Rica and declared that the actions of the government were tantamount to confiscation. After the ruling the matter was completely dropped by the 
United States bank, which decided to join the global rescheduling agreement (Biggs, 1992; Rodríguez, 1992).

Another very publicized retaliation occurred in Ecuador when Citicorp set-off US\$80 million of governmental deposits in early 1989. However, this took place at a time when Ecuador --feeling at no risk due to the conciliatory nature of its moratorium-- had absolutely no defensive strategy in place. The matter is still a subject of negotiations. In the meantime, a strategy has emerged to protect reserves and other assets (Yepez, 1992).

In early 1990 , Peru --which had engaged in isolated legal skirmishes with some lenders in the late 1980s-- found that 25 banks from different countries had as a group initiated court proceedings to avoid legal prescription of their rights to US $\$ 8$ billion of debt on which Peru had made no payment (Latin American Weekly Report, 1990). The action by the banks was interpreted by many as a formality designed to retain a claim on the debts. ${ }^{47}$ In any event, the new Fujimori government --which is actively exploring ways to settle the debt problem-- has negotiated at least a temporary halt in the proceedings.

The initiation of a moratorium always put pressure on short term lines of credit. But most of the countries were able to deal with the problem by aggressively shopping for new lines (this is an attractive low risk business for a bank) and by deployment of countervailing measures. The Garcia administration's system of stabilizing lines with collateral initially enjoyed a degree of success; indeed, after a fall of $40 \%$ between June of 1983 and December 1985, the volume of the country's lines recovered, rising by 20\% through June 1987 (Figueroa, 1992). Thereafter, short term credit started to fall sharply. This, however, was not due to the moratorium as such; rather it reflects the effects of the collapse of the government's political project and heterodox economic program, as well as its populist demand management, which led to the exhaustion of the international reserves that initially were used so effectively to collaterize lines and shore-up domestic confidence.

In view of the very conciliatory nature of its second moratorium, Argentina basically relied on the banks' willingness to respect the captive, or negotiated, lines. Since this short-term credit was not administered from the Central Bank, it was very difficult to control leakage. Nevertheless, the credit situation remained relatively stable and, indeed, in the first year of the moratorium, commercial credit actually rose. The credit crunch that exploded in the second quarter of 1989 was largely part of a general collapse of confidence due to expectations of hyperinflation (Machinea and Sommer, 1992).

Costa Rica's and Ecuador's systems of shopping apparently worked adequately. Ecuador noted a significant net reduction in lines to the public sector, but demand also was low, due to the recessive effects of the adjustment process (Yepez, 1992).

Brazil's centralized administration of captive lines worked reasonably well. Lines were relatively stable during the first half of the year and declined by about US\$ 1 billion thereafter. Thus, at the end of the year, credit volume was only about $6 \%$ below pre-moratorium levels (de 
Freitas, 1992). On the other hand, all voluntary short-term credit --purposely excluded from the previously described forced recycling mechanism-- was lost. That amounted to about US\$1 billion.

As part of a bargaining tactic, in the second moratorium Brazil did not deploy a forced recycling mechanism. Preliminary information suggests that it lost around $35 \%$ of its short-term lines of credit. However, it apparently was able to partially compensate for this loss by more intensive use of domestic savings and by drawing on resources in the country's banking system.

Brazil --the largest developing-country debtor-- may also be the country that has suffered the greatest official pressure during its moratoria. As already mentioned, during the 1987 moratorium the World Bank's lending programme to the government mysteriously stalled. Government officials also apparently were "spooked" by vague rumors of possible trade sanctions by the United States (de Freitas, 1992). In 1990-1991 the government found its lending programs in the World Bank once again stalled. And, in the IDB, the United States used its new veto power to block loans from this institution. Brazil also received a public message of concern from the Group of Seven countries when they issued their official statement for the 1990 Houston Summit.

Finally, in 1987, Brazil and Argentina apparently explored the possibility of cooperating with defensive measures in a joint moratorium. Brazil was already in a moratorium and Argentina was having great difficulty complying with the payments of the rescheduling agreement it had signed with the banks at the beginning of the year. It was later revealed that there were serious conversations at the Ministerial and Presidential levels about cooperation. Nothing, however, materialized from the initiative, perhaps in part because of the sharply deteriorating domestic political and economic situations of the two governments and the inherent difficulties of coordinating a common position on debt (de Freitas, 1992; Machinea and Sommer, 1992; Devlin 1989).

\section{The moratorium as political tool}

The moratorium was an explicit political tool in President Garcia's Peru, Brazil (1987 and 19901991), and Bolivia in 1984. It also could have served as an implicit political tool in countries which were adjusting and demanding large sacrifices from their citizens. The latter strategy is difficult to evaluate even tentatively. The former lends itself more easily to some preliminary comment.

The Peruvian strategy seems to have initially generated political capital for the Garcia administration. There is little doubt about the strong internal consensus regarding the inadequate terms proposed by the creditors. We would postulate that disillusionment with the moratorium -reflected in the Fujimori government's attempt to end it quickly-- really reflected broader disillusionment with the Garcia government's overall economic programme and political project. The turning point in the government's programme seems to have been the announcement of the 
nationalization of the local banking system in July 1987. There also was disillusionment in some domestic circles about the decision to extend the moratorium to multilateral development agencies. As for regional leadership, the strident tone of the García government's debt policy caused other Latin American governments to keep their distance.

It was mentioned that the 1987 Brazilian moratorium could have been partly inspired by the need to divert attention away from the failing Cruzado Plan. But, with the economy already in trouble and no successful new plan emerging, the moratorium did little to reverse the declining political fortunes of the Sarney administration. The government that followed inherited the country's second moratorium. The political capital of this latter restriction was intimately linked to the performance of the government's economic program, which began to falter in the second semester of 1990.

Finally, the 1984 Bolivian moratorium did serve to temporarily soothe the country's powerful labor union.

\section{E. The effectiveness of moratoria as a bargaining tool}

In principle, a payments restriction could be a bargaining tool for a better deal with the creditors. A moratorium generally sharply lowers the market value of a country's debt. It also can decrease the value of neighboring debt due to demonstration effects. If creditors are unable to effectively retaliate to force a settlement favourable to them, then they may eventually be willing to recognize part of the erosion of the value of their assets via concessions in a final debt settlement. Indeed, if the moratorium is perceived to be sustainable in the medium term, creditors will be better off with a settlement because payments will surely rise above moratorium levels. However, creditors also will take into account any negative externalities that may be generated for them by such an agreement.

In any event, one indication of the afore-mentioned leverage may be the fact that Costa Rica and Bolivia have negotiated the most ambitious debt reduction settlements in Latin America to date. In 1990, Costa Rica finalized a Brady Plan agreement which generated a net reduction of principal of $20 \%$ and a net saving of more than $30 \%$ in the country's interest bill. ${ }^{48}$ In transactions carried out in 1988 and 1989, Bolivia bought back about three quarters of its bank debt (plus associated interest arrears) at 11 cents on the dollar; arrears continued to accumulate in those banks which refused to participate. It also was one of the first countries to receive the Paris Club's Toronto terms, which allow for some modest reduction of official bilateral debt (Abbate, Lawrence and Miroux, 1992).

On the other hand, moratoria do not appear to have increased the leverage of other countries. As mentioned, the result of Argentina's first moratorium was a rather standard third round rescheduling. From the beginning, Brazil's 1987 moratorium was interpreted by bankers as politically unsustainable; indeed, the 1988 rescheduling agreement reflected the political need to restore relations with the banks as soon as possible. Venezuela's brief partial moratorium in 
$1989 / 1990$ resulted in a rather standard Brady debt reduction accord. It remains to be seen what type of debt settlements will emerge in the 1990s from Ecuador, Argentina, Brazil, and Peru, as well as other debtors in moratoria with the banks.

\section{CONCLUSIONS}

The debt buildup in Latin America had its origin in domestically induced structural imbalances in the debtor economies, external shocks and a classically permissive expansionary cycle of international credit. Since the correction of imbalances also requires a profound reform of policy regimes and institutions, adjustment and restoration of creditworthiness in the region is a painfully slow process.

Nevertheless, due to the initial effectiveness of the $\mathbb{I L L R}$, and a cooperative attitude in Latin America, defaults were slow to emerge in the region and a world financial collapse was avoided. However, the ILLR's inability to mobilize adequate and predictable compensatory refinancing in support of growth-oriented structural adjustment; the fact that financing was crossconditioned with overly rigid IMF quarterly targets; the inflexibility of rescheduling techniques; the progressive spread of debt fatigue in the countries; and the emergence of serious coordinating problems in the creditor cartel, coupled with the afore-mentioned inherent difficulty and slowness of internal structural reforms, all contributed to a generalization of moratoria as the 1980s progressed.

While the moratoria in the region appear to have been effective as temporary instruments in reducing the internal and external transfers, the strategy clearly has not been generally associated with economic or even political success. Experience suggests that the necessary condition for a turnaround in the economic fortunes of a country in a moratorium is the same as that for a country which continues to service its debt: a minimum threshold of political support (quite broad in a pluralistic regime and more narrow in one that is authoritarian), coupled with a coherent economic programme that addresses itself to eliminating basic disequilibria. With the aforementioned domestic economic and political components firmly in place, an efficiently managed moratorium can temporarily ease the transfer problem and provide more net financing in support of adjustment than the country could expect to obtain from the official international debt program. It was exactly in this context that a moratorium was found to be a critical element in the success of the Costa Rican and Bolivian adjustment and stabilization efforts (Cariaga, 1992; Rodríguez, 1992). Meanwhile, the second moratorium in Brazil was viewed as essential to avoiding an outbreak of hyperinflation (de Freitas, 1992).

It is clear then that declaring a formal moratorium, or falling into a de facto one, will not by itself produce many benefits, and indeed could lead to large net losses. Effective moratoria have been part of a larger and complex policy package. First, it has been essential that a national consensus develops around a serious and sustainable adjustment effort. The financing needs of that effort helped to define and legitimize the moratorium as well as discipline the use of resources. An internationally respectable economic programme also helped to galvanize 
official tolerance abroad and keep image-conscious creditors on the defensive. An effective economic and political programme also strengthened the bargaining power of the economic team by enhancing its credibility and making the moratorium seem more sustainable to the creditors. On the other hand, a deteriorating economic programme merely undermined the credibility of the moratorium and the bargaining power of the economic authorities.

Successful moratoria have been administered with caution and flexibility. Quiet de facto moratoria have been more effective than formal ones. Maintenance of a constructive dialogue with the creditors has proven, not only tactically useful, but also practical. In effect, a moratorium must be temporary in nature, because while it can relieve the negative cash-flow effects of overindebtedness, it cannot relieve its distorting impact on private investment decisions. ${ }^{49}$ Thus, the sooner the government can negotiate a satisfactory settlement with its creditors, the better. Symbolic or partial payments on part of the current debt service may be a way to keep that dialogue fluid. Not only does it display good faith, but it also keeps banks interested in dialogue; on the one hand, it gives them an opportunity to pressure the country for higher payments; on the other, they know that intransigence on their part could lead to a cut in the payments that are being made.

A moratorium has been less conflictive when the authorities' proposals for a settlement have not publicly challenged the prevailing framework of official debt management. An IMF program, or at least an Article IV consultation, has proved useful, especially when it has validated ex-post an economic programme that the domestic authorities had already implemented and could successfully commit themselves to; it has also been a way to put an official umbrella over temporary arrears-based financing of adjustment. Unfortunately, the Fund can be an unreliable ally because of its vulnerabilility to the changing political winds in the Group of Seven countries. As already mentioned, pressure by the banks on the Group of Seven over the Brady Plan's tolerance of arrears has already produced one important setback for the international management of the debt problem.

Arrears with multilateral agencies have proven counterproductive. They erode the tolerance of the official sector and --given a political unwillingness to exploit the possibilities of rescheduling--, once accumulated, are extremely difficult to eliminate (O'Connell, 1992). Arrears with the Paris Club are counterproductive when they affect countries whose political support is needed during the moratoria. Friendly gestures to key Group of Seven countries and lead banks in non-debt related matters have also been a way to reduce tension around a moratorium. $^{50}$

No matter how conciliatory a moratorium may be, the Ecuadorian experience with a setoff confirmed the need for protection of reserves and other assets. Short-term lines have also often needed protection. While problems in this area are inevitable, experience has shown that there are effective, albeit somewhat costly, ways to protect liquidity.

Countries must also anticipate that a moratorium against one set of creditors will likely have negative repercussions on the disposition of other lenders to disburse. In many cases, 
however, this will be only a theoretical problem since loans are often tied to unrealistic conditionality and also can be blocked by creditor "revulsion" during a systemic crisis.

Finally, it should be mentioned that the bigger a country's debt is, the more likely there will be conflict around a moratorium. From 1982 onward, Costa Rica was careful to avoid conflict with its creditors. However, it was continually in a moratorium and quietly proposed unconventional payment formulas, based on its capacity to pay (Rodríguez, 1992). Had the country been a megadebtor, its unconventional tactics might have drawn more publicity and pushed the country into more conflict.

In sum, a successful temporary moratorium strategy requires a complex set of conditions that most countries have not been able to organize. Nevertheless, as long as the international debt strategy does not adequately address the problem of overindebtedness and related structural impediments to growth, moratoria will remain a problem in the region. ${ }^{51}$

The Brady Plan's original idea of tolerating arrears as a way of temporarily financing adjustment was a valuable innovation. First, it could break down the bankers' resistance to debt reduction and act as an "escape valve" for the Brady Plan's serious problem of underfunding. ${ }^{52}$ It also allowed moratorium countries to link-up in one form or another with the IMF and, thereby, avoid go-it-alone policies like those of Peru, which sometimes can become very destructive. Unfortunately, however, bankers are increasingly concerned about the precedents of settling with countries in arrears. Moreover, their leverage in official circles has seemed to increase recently, as in the case of Brazil leading the IMF and other multilateral lenders to relink their adjustment programs to prior agreements with the banks. A generalization of this trend --without a corresponding effort to strengthen the current international debt strategy-would increase the requirements for internal economic and political coherence in the moratorium countries. Indeed, in view of the current shortcomings of the international debt strategy, the more internal weaknesses push a country into a settlement with its creditors, the less satisfactory that settlement is likely to be.

\section{Notes}

1. In contrast to domestic markets, where the LLR is well defined and usually located in a central bank and/or the government treasury, at the international level its operation is much more complex and ad hoc. However postwar practice suggests that it is constituted by an informal, decentralized alliance of the G-7 governments, some of their big commercial banks, and major multilateral lenders, especially the IMF. While decentralized, the axis of movement is the G-7 governments, and that leadership is often delegated to the country with the closest political and commercial ties to the country or region in crisis.(See Wellons, 1987.)

2. For instance, major U.S. banks had loans to Latin America in excess of $180 \%$ of their capital (ECLAC, 1988).

3. The negotiated price of the loans was between $100 \%$ and $250 \%$ greater than that prevailing before the crisis (Devlin, 1989). 
4. For more details on the debt strategy, see ECLAC (1985).

5. Wellons (1987). The net income of the banks actually rose in the early years of the crisis (ECLAC, 1988).

6. The nature of each round of rescheduling is fully analyzed by ECLAC $(1985,1988,1990 \mathrm{a})$.

7. By the end of the year, however, Costa Rica and Venezuela had also regularized their payments.

8. "Moratorium" is used loosely here to describe the existence of protracted interest arrears and the absence of a clear agreement to eliminate them. Arrears on amortization payments occurred frequently in the $1980 \mathrm{~s}$ but these were not very conflictive as long as the interest on the debt was paid promptly.

9. The defaults started in early 1931 with Bolivia, Peru, Chile, Costa Rica, Colombia and Brazil, followed by El Salvador and Uruguay in 1932 and by Panama and Cuba in 1933 . By the mid 1930s, 80\% of the region's debt was in default. The only countries to avoid default were Argentina (on federal debt), Haiti and the Dominican Republic. (Skiles 1988; ECLAC 1965.)

10. However, the country was adversely affected by the systemic withdrawal of creditors from the region as a whole. Consequently, Colombia has had to negotiate administrative refinancing of amortization payments.

11. The data on arrears are evidently very poor and the figures in the tables should therefore be used with caution. We suspect that the tables underestimate arrears. For instance, the commercial banks, which presumably are very strict about such matters, provide figures for interest arrears on their loans (See Annex, Table A 1) that often exceed the interest arrears on the total debt presented in Table 1. The figures also differ from those found in IMF balance of payments data and national sources.

12. Arrears also were registered in Brazil. These, however, were extremely minor and related to technical aspects of the debt negotiations.

13. For details on the organization of the Consensus, see Tussie (1988).

14. Venezuela more quietly stonewalled by not agreeing to a rescheduling and accumulating arrears on amortization payments. However, by remaining current on the payment of interest, it kept conflict levels low (Fossati, 1991).

15. For the rescheduling and new money, respectively, the military government had agreed in the first round to a spread over LIBOR of $2.13 \%$ and $2.50 \%$, an amortization period of 7 and 5 years and a commission of $1.25 \%$ flat. The respective figures for the third round of reschedulings were $1.38 \%$ and $1.63 \%, 12$ and 10 years, and a commission of $0.58 \%$ flat paid only on the new money. Mexico earlier had initiated the third round by rescheduling with a margin of $1.13 \%$ over LIBOR and a maturity of 14 years. In contrast with Argentina, Mexico did not request new "involuntary" loans, in part because it thought by forgoing them it could re-enter the voluntary credit market. The strategy of course did not work.

16. This explains the sharp rise in this country's interest arrears in 1985. The policy of withholding payments to the Paris Club lasted until early 1986. (See de Freitas, 1992).

17. Mr. Baker promised to raise new net lending of US $\$ 29$ billion over 3 years, of which US $\$ 20$ billion would be provided by the commercial banks.

18. Mexico's spread was $0.81 \%$ for both the rescheduled principal and new money. The amortization periods were 20 and 12 years, respectively. No commissions were charged. The rescheduling covered maturities over the period 1985-1990. 
19. For example, U.S. banks experienced a second-quarter loss of US\$11 billion due to the adding of US\$21 billion to loan loss reserves for developing country debt. (Skidmore 1987).

20. Data on the loan loss reserves of commercial banks can be found in ECLAC (1990a).

21. A full analysis of the Brady Plan is found in ECLAC (1990a).

22. For an analysis of the debt reduction agreement, see ECLAC (1990).

23. A description of the agreements can be found in ECLAC (1990b).

24. That is, well above 2. This conventional criterion of high indebtedness has emerged based on the rationale that, with interest rates at about $8 \%-10 \%$, such a level of indebtedness would only absorb $16 \%-20 \%$ of exports for the payment of interest and allow the debt-service ratio to be around $24 \%-30 \%$.

25. This criterion is equivalent to Simonsen's "weak solvency test", i.e., that the interest rate does not exceed the rate of growth of exports (Simonsen, 1985).

26. The IMF concurred, at the time, with this stance. Nevertheless, given the meager amount of its resources relative to the new international financial scene, this concurrence was more conceptual than practical.

27. See ECLAC, (1990b; Table 18).

28. To say nothing of Bolivia, in which interest payments on the public debt al ready committed two thirds of public revenues.

29. The assumption of private external debt, which was forced on the countries by the creditor cartel, represented an addition to interest payments by the public sector that may have amounted to $40 \%$ in Argentina, Chile and Venezuela and to around 20\% in Ecuador, Mexico and Uruguay (see ECLAC, 1989; chap. X).

30. In part, the rise in the proportion of public resources absorbed by interest payments on the external debt was brought on by the real devaluations required by external adjustment. If those real devaluations had not taken place, fiscal resources (in national currency) required to pay interest on the external public debt would have been $30 \%$ less in Chile, Mexico and Uruguay; more than 20\% less in Argentina and Ecuador; and around 10\% less than the actual amounts in Brazil, Colombia, Peru and Venezuela (ECLAC, 1989; chap. X).

31. The effects of the debt reduction itself were extremely modest. See ECLAC (1990c).

32. A situation that in many cases has been significantly aggravated, as already noted, by the assumption of private debt by the public sector. The absorption of debt was largely forced upon the governments by their creditors. Since most of these obligations were originally unguaranteed, there clearly was little technical justification for the pressure placed on debtor governments to assume bad debts ex post and without compensation.

33. It should be remembered, however, that in the year prior to falling into a de facto moratorium with most of its creditors, Cuba initiated a vocal campaign against the international debt strategy, affirming that the debt was unpayable and should therefore be forgiven. But interestingly, the country's arguments were carefully directed at the region's debt as a whole rather than the Cuban situation as such. Indeed, during the campaign Cuba was punctually serving its obligations (Castro 1985).

34. The moratorium also might have been a direct provocation of U.S. Treasury Secretary Baker, who, a few weeks earlier, had intervened in Brazil's favor to resolve a serious conflict between the country and the Paris Club. For the details, see de Freitas (1992). 
35. The challenge over the travel expenses would seem technically justified since the debt problem arose not just out of overborrowing, but also overlending.

36. The 1987 moratorium was announced after the Cruzado Plan had clearly collapsed.

37. Peru did this because it found that private sector debt service had become a vehicle for flight capital (Figueroa, 1992).

38. A delay of six months or more is considered serious. As mentioned earlier, Honduras eliminated most of its arrears in a consultative group operation in 1990. Peru and Nicaragua arrived at settlements with their multilateral creditors in 1991.

39. For a good summary of some of the perceived threats from default see Cline (1984).

40. For a technical discussion of the set-off, see Biggs (1992).

41. In the rescheduling agreements the banks frequently committed themselves to keeping open a specified amount of short term credit.

42. Indeed, after the announcement of the 1987 moratorium there was open criticism in certain news media and in professional circles.

43. Venezuela's turnaround is very recent. It did not become a model adjuster until 1989. Its determined internal efforts were moreover greatly aided by a rise in the price of petroleum and an opportunity to increase export volume on account of a breakdown in OPEC's quota system during the Gulf War. Venezuela also did not play entirely by the conventional rules of the game in the debt negotiations, e.g., it had a moratorium on amortization payments in 1982-1983 and substantial interest arrears during part of the period 1989/1990.

44. Stallings (1990) suggests that the authoritative nature of the regimes may have been an important factor in their successful adjustment.

45. Mention should be made of some of the additional factors in play here. In Costa Rica, its important geopolitical position in Central America meant that the country received an average of $\$ 175$ million per annum in official grants. This may help to explain the mild character of its credit moratorium. Meanwhile, Bolivia also benefitted from official transfers --especially in 1987-1988, when they averaged $\$ 140$ millon per annum-- and considerable repatriation of resident capital in the first three years of Paz Estenssoro's economic program. Peru's overall transfer displays an adverse shift in 1989 due to a bulge in the flight of capital which corresponded to a sharp reverse in expectations about the country's economic program. The adverse trend in Argentina in 1989 was also due to the collapse of its economic program and expectations in April of that year.

46. For a detailed legal analysis see Biggs (1992).

47. Nevertheless, in delicate legal matters like this there always is the potential threat of escalating problems.

48. Note that the banks did not include arrears in the debt reduction exercise; they were rescheduled on less favorable terms. See ECLAC (1990b and 1990c).

49. This is because private investors, among other things, must negotiate a queue for foreign exchange and for public payments as well as confront undue uncertainty over key variables such as the exchange rate, interest rates, foreign credit lines, etc. 
50. Bolivia showed sensitivity to the U.S.'s concern about drug traffic. Argentina's privatizations --in which large banks have shown an interest-- and cooperation with the allies in the Gulf War have probably helped to reduce tensions around that country's moratorium.

51. For an analysis of the shortcomings of the debt strategy and proposals to overcome them, see ECLAC (1990a).

52. An analysis of the underfunding problem is in ECLAC (1990a). Essentially, underfunding in Brady's voluntary system leads to modest debt reduction. Hence, in situations of underfunding, temporary arrears may be a surer, albeit less efficient, route to financing IMF adjustment programs. 

$\mathbb{T} \mathbb{A} \mathbb{E}$ 
. 
Table 1

LATIN AMERICA: INTEREST ARREARS ON THE EXTERNAL DEBT (Millions of dollars)

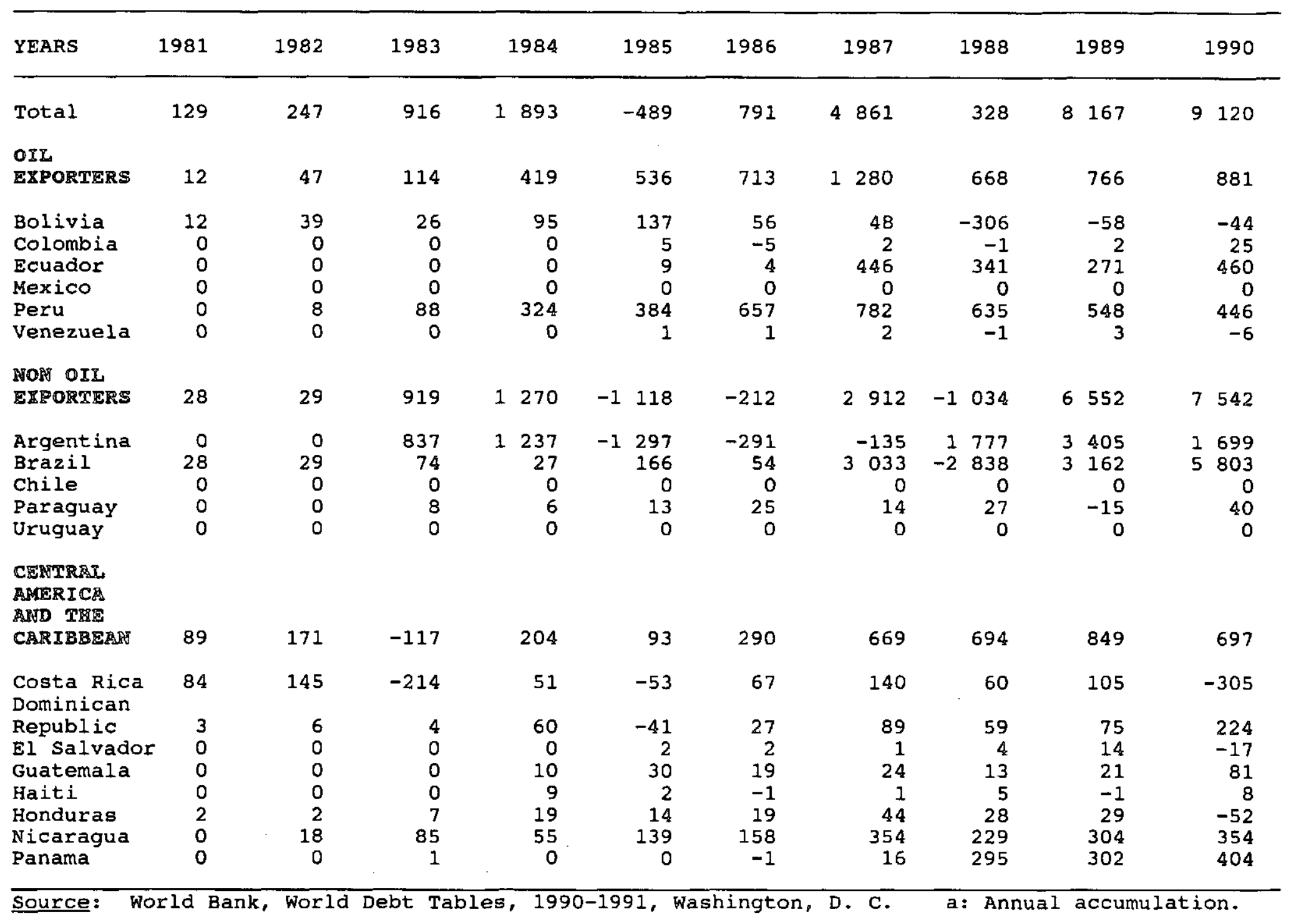


Table 2

LATIN AMERICA AND THE CARIBBEAN: ACCUMULATED ARREARS AS A PERCENT OF ACCUMULATED DEBT

(1981=base year)

Percentages

\begin{tabular}{|c|c|c|c|c|c|c|c|c|c|}
\hline YEARS & 1982 & 1983 & 1984 & 1985 & 1986 & 1987 & 1988 & 1989 & 1990 \\
\hline TOTAL & 1 & 1 & 3 & 2 & 2 & 5 & 6 & 12 & 20 \\
\hline $\begin{array}{l}\text { OIL } \\
\text { EXPORTERS }\end{array}$ & - & - & 1 & 2 & 3 & 4 & 6 & 7 & 9 \\
\hline $\begin{array}{l}\text { Bolivia } \\
\text { Colombia } \\
\text { Ecuador } \\
\text { Mexico } \\
\text { Peru } \\
\text { Venezuela }\end{array}$ & $\begin{array}{r}24 \\
0 \\
0 \\
0 \\
1 \\
0\end{array}$ & $\begin{array}{l}8 \\
0 \\
0 \\
0 \\
4 \\
0\end{array}$ & $\begin{array}{r}18 \\
0 \\
0 \\
0 \\
13 \\
0\end{array}$ & $\begin{array}{r}24 \\
-0 \\
1 \\
0 \\
19 \\
-\end{array}$ & $\begin{array}{r}19 \\
- \\
1 \\
0 \\
28 \\
-\end{array}$ & $\begin{array}{r}20 \\
- \\
14 \\
0 \\
33 \\
-\end{array}$ & $\begin{array}{r}6 \\
- \\
24 \\
0 \\
44 \\
-\end{array}$ & $\begin{array}{r}5 \\
- \\
28 \\
0 \\
50 \\
-\end{array}$ & $\begin{array}{r}-1 \\
36 \\
0 \\
52 \\
0\end{array}$ \\
\hline $\begin{array}{l}\text { NON OIL } \\
\text { EXPORTERS }\end{array}$ & - & 3 & 5 & 2 & 1 & 5 & 4 & 16 & 31 \\
\hline $\begin{array}{l}\text { Argentina } \\
\text { Brazil } \\
\text { Chile } \\
\text { Paraguay } \\
\text { Uruguay }\end{array}$ & $\begin{array}{l}0 \\
- \\
0 \\
0 \\
0\end{array}$ & $\begin{array}{l}6 \\
1 \\
0 \\
2 \\
0\end{array}$ & $\begin{array}{r}14 \\
1 \\
0 \\
3 \\
0\end{array}$ & $\begin{array}{l}4 \\
1 \\
0 \\
3 \\
0\end{array}$ & $\begin{array}{l}2 \\
1 \\
0 \\
5 \\
0\end{array}$ & $\begin{array}{l}1 \\
8 \\
0 \\
5 \\
0\end{array}$ & $\begin{array}{l}8 \\
2 \\
0 \\
7 \\
0\end{array}$ & $\begin{array}{r}18 \\
15 \\
0 \\
6 \\
0\end{array}$ & $\begin{array}{r}29 \\
39 \\
0 \\
13 \\
0\end{array}$ \\
\hline $\begin{array}{l}\text { CENTRAL AMERICA } \\
\text { AND THE CARIBBEAN }\end{array}$ & 8 & 1 & 4 & 4 & 6 & 10 & 15 & 20 & 24 \\
\hline $\begin{array}{l}\text { Costa Rica } \\
\text { Dominican Republic } \\
\text { El Salvador } \\
\text { Guatemala } \\
\text { Haiti } \\
\text { Honduras } \\
\text { Nicaragua } \\
\text { Panama }\end{array}$ & $\begin{array}{r}74 \\
2 \\
0 \\
0 \\
0 \\
1 \\
4 \\
0\end{array}$ & $\begin{array}{r}-7 \\
1 \\
0 \\
0 \\
0 \\
2 \\
8 \\
-\end{array}$ & $\begin{array}{r}-2 \\
8 \\
0 \\
1 \\
7 \\
5 \\
7 \\
-\end{array}$ & $\begin{array}{r}-6 \\
2 \\
- \\
3 \\
6 \\
5 \\
11 \\
-\end{array}$ & $\begin{array}{r}- \\
4 \\
- \\
4 \\
4 \\
6 \\
12 \\
0\end{array}$ & $\begin{array}{r}9 \\
8 \\
1 \\
6 \\
3 \\
7 \\
19 \\
1\end{array}$ & $\begin{array}{r}15 \\
12 \\
1 \\
8 \\
5 \\
9 \\
22 \\
20\end{array}$ & $\begin{array}{r}23 \\
15 \\
2 \\
10 \\
5 \\
11 \\
25 \\
41\end{array}$ & $\begin{array}{r}- \\
26 \\
1 \\
15 \\
6 \\
6 \\
28 \\
65\end{array}$ \\
\hline
\end{tabular}

Source: World Bank, World Debt Tables 1989-1990; 1990-1991, Washington, D. C. a: Long term debt.

$(-)=$ Not significant. 
Table 3

LATIN AMERICA: DEBT/EXPORT COEFFICIENTS (Percentages)

\begin{tabular}{lllll}
\hline Countries & 1979 & 1982 & 1986 & 1990 \\
\hline Group I & & & & \\
& & & & \\
Argentina & 207 & 475 & 610 & 499 \\
Bolivia & 227 & 327 & 530 & 389 \\
Brazil & 353 & 818 & 460 & 351 \\
Costa Rica & 213 & 285 & 281 & 155 \\
Ecuador & 147 & 198 & 345 & 363 \\
Peru & 228 & 281 & 429 & 416 \\
Group II & & & & \\
& & & & \\
Colombia & 115 & 232 & 233 & 209 \\
Chile & 184 & 370 & 405 & 167 \\
Mexico & 262 & 337 & 459 & 258 \\
Uruguay & 141 & 276 & 349 & 338 \\
Venezuela & 154 & 183 & 347 & 161 \\
\end{tabular}

Source: CEPAL, Economic Development Division. : Total external debt. 
Table 4

LATIN AMERICA: PUBLIC DEBT AS A PROPORTION OF TOTAL EXTERNAL DEBT (Percentages)

\begin{tabular}{|c|c|c|c|c|c|c|c|c|c|}
\hline & 1980 & 1982 & 1983 & 1984 & 1985 & 1986 & 1987 & 1988 & 1989 \\
\hline \multicolumn{10}{|l|}{ Group I } \\
\hline $\begin{array}{l}\text { Argentina } \\
\text { Bolivia } \\
\text { Brazil } \\
\text { Costa Rica } \\
\text { Ecuador } \\
\text { Peru }\end{array}$ & $\begin{array}{l}37.5 \\
80.8 \\
57.5 \\
61.8 \\
55.0 \\
61.9\end{array}$ & $\begin{array}{l}36.4 \\
85.2 \\
55.7 \\
65.6 \\
50.4 \\
56.6\end{array}$ & $\begin{array}{l}55.4 \\
80.0 \\
60.9 \\
75.1 \\
73.0 \\
68.4\end{array}$ & $\begin{array}{l}54.6 \\
78.1 \\
67.2 \\
79.7 \\
79.0 \\
70.3\end{array}$ & $\begin{array}{l}73.3 \\
73.1 \\
70.6 \\
80.2 \\
82.7 \\
72.4\end{array}$ & $\begin{array}{l}78.1 \\
73.0 \\
74.9 \\
79.0 \\
88.5 \\
70.2\end{array}$ & $\begin{array}{l}84.2 \\
79.2 \\
74.0 \\
78.4 \\
85.8 \\
68.3\end{array}$ & $\begin{array}{l}80.9 \\
81.3 \\
77.7 \\
78.0 \\
84.0 \\
65.8\end{array}$ & $\begin{array}{l}79.4 \\
82.7 \\
75.7 \\
77.9 \\
83.3 \\
63.7\end{array}$ \\
\hline \multicolumn{10}{|l|}{ Group II } \\
\hline $\begin{array}{l}\text { Colombia } \\
\text { Chile } \\
\text { Mexico } \\
\text { Uruguay } \\
\text { Venezuela }\end{array}$ & $\begin{array}{l}58.9 \\
38.9 \\
59.1 \\
67.9 \\
36.1\end{array}$ & $\begin{array}{l}58 \cdot 1 \\
30 \cdot 3 \\
59 \cdot 9 \\
64 \cdot 2 \\
38.7\end{array}$ & $\begin{array}{l}60.2 \\
36.8 \\
71.8 \\
76.2 \\
38.7\end{array}$ & $\begin{array}{l}64 \cdot 2 \\
53 \cdot 8 \\
73.5 \\
77.3 \\
50.9\end{array}$ & $\begin{array}{l}67 \cdot 2 \\
63 \cdot 3 \\
75 \cdot 1 \\
68.8 \\
50.2\end{array}$ & $\begin{array}{l}79.3 \\
69.5 \\
75.2 \\
74.1 \\
73.1\end{array}$ & $\begin{array}{l}81.3 \\
72.3 \\
77.1 \\
72.5 \\
71.2\end{array}$ & $\begin{array}{l}81.5 \\
69.9 \\
80.0 \\
77.2 \\
71.4\end{array}$ & $\begin{array}{l}82.9 \\
59.5 \\
79.7 \\
79.1 \\
76.5\end{array}$ \\
\hline
\end{tabular}

Source: World Bank, World Debt Tables, 1990-1991, Washington D. C., 1990. 
Table 5

LATIN AMERICA: RATIO OF INTEREST PAID OR ACCRUED ON PUBLIC FOREIGN DEBT AND CURRENT PUBLIC REVENUES ${ }^{a}$

(Percentages)

\begin{tabular}{|c|c|c|c|c|c|c|c|c|c|c|c|c|c|}
\hline Countries & Interest & 1978 & 1979 & 1980 & 1981 & 1982 & 1983 & 1984 & 1985 & 1986 & 1987 & 1988 & 1989 \\
\hline Group I & & & & & & & & & & & & & \\
\hline $\begin{array}{l}\text { Argentina } \\
\text { Bolivia } \\
\text { Brazil } \\
\text { Costa Rica } \\
\text { Ecuador } \\
\text { Peru } \\
\text { Grupo II }\end{array}$ & $\begin{array}{l}\text { Paid } \\
\text { Accrued } \\
\text { Paid } \\
\text { Accrued } \\
\text { Paid } \\
\text { Accrued } \\
\text { Paid } \\
\text { Accrued } \\
\text { Paid } \\
\text { Accrued } \\
\text { Paid } \\
\text { Accrued }\end{array}$ & $\begin{array}{l}3.0 \\
3.0 \\
\ldots \\
\ldots \\
\ldots \\
\ldots \\
\ldots \\
\ldots \\
\ldots \\
\ldots\end{array}$ & $\begin{array}{c}2.3 \\
2.3 \\
\ldots \\
\ldots \\
\ldots \\
\ldots \\
\cdots \\
8.3 \\
8.3 \\
13.3\end{array}$ & $\begin{array}{r}2.3 \\
2.3 \\
20.2 \\
20.2 \\
6.6 \\
6.6 \\
9.8 \\
9.8 \\
9.6 \\
9.6 \\
13.3 \\
12.5\end{array}$ & $\begin{array}{r}4.1 \\
4.1 \\
26.2 \\
26.2 \\
7.5 \\
7.5 \\
14.2 \\
14.2 \\
12.7 \\
12.7 \\
12.5 \\
13.0\end{array}$ & $\begin{array}{r}10.3 \\
10.3 \\
50.1 \\
63.6 \\
8.8 \\
8.8 \\
12.0 \\
42.2 \\
17.5 \\
17.5 \\
13.0 \\
20.5\end{array}$ & $\begin{array}{l}11.4 \\
16.6 \\
79.0 \\
82.9 \\
11.2 \\
11.2 \\
47.8 \\
30.5 \\
12.9 \\
12.9 \\
20.5 \\
23.1\end{array}$ & $\begin{array}{r}12.8 \\
18.8 \\
41.5 \\
59.8 \\
11.6 \\
11.6 \\
16.8 \\
20.6 \\
26.7 \\
26.7 \\
9.1 \\
22.4\end{array}$ & $\begin{array}{r}20.5 \\
15.1 \\
16.5 \\
39.2 \\
10.9 \\
10.9 \\
24.0 \\
20.1 \\
18.4 \\
18.4 \\
8.2 \\
16.2\end{array}$ & $\begin{array}{r}15.2 \\
13.9 \\
7.3 \\
13.5 \\
6.7 \\
6.7 \\
12.3 \\
17.2 \\
21.3 \\
21.3 \\
5.9 \\
12.6\end{array}$ & $\begin{array}{r}16.3 \\
15.6 \\
12.1 \\
20.0 \\
7.0 \\
10.9 \\
7.8 \\
21.5 \\
10.3 \\
28.6 \\
5.2 \\
19.0\end{array}$ & $\begin{array}{r}\ldots \\
\ldots \\
\ldots \\
12 . \\
9.2 \\
\ldots \\
\ldots \\
\cdots \\
\ddot{2} .5 \\
22.7\end{array}$ & $\begin{array}{l}\cdots \\
\cdots \\
\cdots \\
\cdots \\
\cdots \\
\cdots \\
\cdots \\
30 \\
\cdots\end{array}$ \\
\hline $\begin{array}{l}\text { Colombia } \\
\text { Chile } \\
\text { Mexico } \\
\text { Uruguay } \\
\text { Venezuela }\end{array}$ & $\begin{array}{l}\text { Paid } \\
\text { Paid } \\
\text { Paid } \\
\text { Paid } \\
\text { Paid }\end{array}$ & $\begin{array}{l}3.6 \\
5.8 \\
\ldots .4 \\
\ldots\end{array}$ & $\begin{array}{l}3.7 \\
4.8 \\
\ldots \\
3.8 \\
\ldots\end{array}$ & $\begin{array}{l}4.3 \\
4.8 \\
8.5 \\
4.1 \\
5.7\end{array}$ & $\begin{array}{l}6.7 \\
4.9 \\
9.3 \\
3.5 \\
5.4\end{array}$ & $\begin{array}{r}7.8 \\
6.9 \\
16.8 \\
5.1 \\
7.3\end{array}$ & $\begin{array}{r}8.0 \\
7.7 \\
18.6 \\
13.0 \\
9.1\end{array}$ & $\begin{array}{r}6.4 \\
13.9 \\
16.9 \\
21.6 \\
6.9\end{array}$ & $\begin{array}{r}11.3 \\
16.3 \\
18.0 \\
20.4 \\
7.8\end{array}$ & $\begin{array}{l}10.9 \\
19.4 \\
21.7 \\
12.8 \\
12.4\end{array}$ & $\begin{array}{l}13.4 \\
15.7 \\
19.2 \\
11.8 \\
12.6\end{array}$ & $\begin{array}{r}12.7 \\
16.5 \\
\ldots \\
\ldots\end{array}$ & $\begin{array}{r}13.7 \\
\ldots \\
14.4 \\
\ldots \\
\ldots\end{array}$ \\
\hline
\end{tabular}

Source: CEPAL, Economic Development Division.

a: Includes total revenues of the general government plus operating surplus (or deficit) of public enterprises. $(\ldots)=$ Unavailable. 
Table 6

LATIN AMERICA: ROLLOVER RATIOS ON TOTAL FOREIGN DEBT SERVICE (Percentages)

\begin{tabular}{|c|c|c|c|c|c|c|c|c|c|c|}
\hline Countries & 1980 & 1981 & 1982 & 1983 & 1984 & 1985 & 1986 & 1987 & 1988 & 1989 \\
\hline \multicolumn{11}{|l|}{ Group I } \\
\hline $\begin{array}{l}\text { Argentina } \\
\text { Bolivia } \\
\text { Brazil } \\
\text { Costa Rica } \\
\text { Ecuador } \\
\text { Peru }\end{array}$ & $\begin{array}{r}74 \\
99 \\
119 \\
95 \\
86 \\
134\end{array}$ & $\begin{array}{r}55 \\
93 \\
100 \\
146 \\
79 \\
137\end{array}$ & $\begin{array}{r}176 \\
208 \\
145 \\
231 \\
150 \\
97\end{array}$ & $\begin{array}{r}193 \\
109 \\
120 \\
48 \\
78 \\
98\end{array}$ & $\begin{array}{l}343 \\
477 \\
116 \\
171 \\
135 \\
185\end{array}$ & $\begin{array}{l}104 \\
624 \\
158 \\
102 \\
124 \\
285\end{array}$ & $\begin{array}{l}150 \\
200 \\
167 \\
216 \\
103 \\
498\end{array}$ & $\begin{array}{r}168 \\
190 \\
176 \\
541 \\
92 \\
439\end{array}$ & $\begin{array}{l}246 \\
\cdots \\
330 \\
168 \\
707\end{array}$ & $\begin{array}{l}13 \dot{135} \\
430 \\
104 \\
856\end{array}$ \\
\hline \multicolumn{11}{|l|}{ Group II } \\
\hline $\begin{array}{l}\text { Colombia } \\
\text { Chile } \\
\text { Mexico } \\
\text { Uruguay } \\
\text { Venezuela }\end{array}$ & $\begin{array}{r}83 \\
73 \\
98 \\
118 \\
127\end{array}$ & $\begin{array}{r}77 \\
74 \\
90 \\
77 \\
194\end{array}$ & $\begin{array}{r}92 \\
136 \\
98 \\
69 \\
155\end{array}$ & $\begin{array}{r}100 \\
197 \\
114 \\
67 \\
281\end{array}$ & $\begin{array}{r}96 \\
68 \\
180 \\
382 \\
1296\end{array}$ & $\begin{array}{r}98 \\
133 \\
170 \\
997 \\
1536\end{array}$ & $\begin{array}{r}141 \\
170 \\
377 \\
1954\end{array}$ & $\begin{array}{l}221 \\
165 \\
182 \\
256 \\
699\end{array}$ & $\begin{array}{l}131 \\
178 \\
396 \\
531 \\
778\end{array}$ & $\begin{array}{l}238 \\
816 \\
505 \\
593\end{array}$ \\
\hline
\end{tabular}

Source: CEPAL, Economic Development Division.

Rollover ratio is debt service (interest and amortization, excluding shortterm) divided by disbursements (excluding short-term) of new loans.

$(.$.$) = Unavailable$ 
Table 7

LATIN AMERTCA: INTERNATIONAL RESERVES ${ }^{a}$ IN RELATION

TO IMPORTS OF GOODS AND SERVICES

(Numbers of months of imports)

\begin{tabular}{|c|c|c|c|c|c|c|c|c|c|c|c|c|}
\hline Countries & 1978 & 1979 & 1980 & 1981 & 1982 & 1983 & 1984 & 1985 & 1986 & 1987 & 1988 & 1989 \\
\hline \multicolumn{13}{|l|}{ Group I } \\
\hline $\begin{array}{l}\text { Argentina } \\
\text { Bolivia } \\
\text { Brazil } \\
\text { Costa Rica } \\
\text { Ecuador } \\
\text { Peru }\end{array}$ & $\begin{array}{r}12.0 \\
2.2 \\
8.6 \\
1.8 \\
3.5 \\
2.3\end{array}$ & $\begin{array}{r}12.8 \\
1.9 \\
5.0 \\
0.9 \\
3.3 \\
7.3\end{array}$ & $\begin{array}{l}6.2 \\
1.5 \\
2.5 \\
1.1 \\
4.2 \\
6.0\end{array}$ & $\begin{array}{l}3.4 \\
1.0 \\
2.9 \\
1.2 \\
2.4 \\
2.9\end{array}$ & $\begin{array}{l}4.6 \\
2.6 \\
1.9 \\
2.6 \\
1.3 \\
3.4\end{array}$ & $\begin{array}{l}2.4 \\
2.6 \\
2.7 \\
3.3 \\
4.2 \\
4.4\end{array}$ & $\begin{array}{l}2.5 \\
4.6 \\
7.8 \\
3.9 \\
3.6 \\
6.5\end{array}$ & $\begin{array}{l}7.4 \\
3.4 \\
7.5 \\
4.8 \\
4.0 \\
7.9\end{array}$ & $\begin{array}{l}5.0 \\
2.3 \\
3.8 \\
4.7 \\
3.5 \\
4.5\end{array}$ & $\begin{array}{l}2.5 \\
1.3 \\
3.9 \\
3.6 \\
2.2 \\
1.7\end{array}$ & $\begin{array}{l}5.5 \\
1.7 \\
4.2 \\
4.7 \\
2.2 \\
1.5\end{array}$ & $\begin{array}{l}2.8 \\
3.2 \\
3.7 \\
4.3 \\
2.9 \\
2.9\end{array}$ \\
\hline \multicolumn{13}{|l|}{ Grupo II } \\
\hline $\begin{array}{l}\text { Colombia } \\
\text { Chile } \\
\text { Mexico } \\
\text { Uruguay } \\
\text { Venezuela }\end{array}$ & $\begin{array}{l}8.3 \\
3.6 \\
1.9 \\
4.4 \\
4.8\end{array}$ & $\begin{array}{r}11.8 \\
4.5 \\
1.5 \\
2.6 \\
6.2\end{array}$ & $\begin{array}{r}10.6 \\
5.3 \\
1.4 \\
2.1 \\
5.2\end{array}$ & $\begin{array}{l}9.5 \\
4.7 \\
1.5 \\
2.5 \\
5.7\end{array}$ & $\begin{array}{l}6.9 \\
4.3 \\
0.5 \\
0.9 \\
4.0\end{array}$ & $\begin{array}{r}4.0 \\
6.0 \\
3.7 \\
2.1 \\
10.1\end{array}$ & $\begin{array}{r}3.1 \\
6.2 \\
5.4 \\
1.5 \\
10.7\end{array}$ & $\begin{array}{r}3.8 \\
7.5 \\
3.2 \\
2.0 \\
12.7\end{array}$ & $\begin{array}{l}6.4 \\
6.4 \\
4.2 \\
4.9 \\
7.7\end{array}$ & $\begin{array}{l}6.5 \\
5.5 \\
8.7 \\
4.5 \\
6.6\end{array}$ & $\begin{array}{l}6.1 \\
5.7 \\
2.5 \\
4.4 \\
2.6\end{array}$ & $\begin{array}{l}6.4 \\
4.3 \\
2.4 \\
4.0 \\
5.3\end{array}$ \\
\hline
\end{tabular}

Source: CEPAL, Economic Development Division.

a Total reserves minus gold. 
Table 8

LATIN AMERICA: RATIO OF TOTAL IMPORTS TO TOTAL EXPORTS (Percentages)

\begin{tabular}{lrrrrrrrrrrrr}
\hline Countries & 1978 & 1979 & 1980 & 1981 & 1982 & 1983 & 1984 & 1985 & 1986 & 1987 & 1988 & 1989 \\
\hline Argentina & 66 & 96 & 132 & 107 & 71 & 63 & 62 & 53 & 77 & 94 & 66 & 54 \\
Bolivia & 135 & 131 & 81 & 114 & 79 & 86 & 81 & 98 & 126 & 140 & 109 & 90 \\
Brazil & 121 & 130 & 127 & 107 & 113 & 83 & 61 & 61 & 76 & 69 & 55 & 64 \\
Costa Rica & 126 & 138 & 138 & 111 & 93 & 101 & 98 & 104 & 96 & 112 & 105 & 113 \\
Ecuador & 156 & 110 & 102 & 109 & 109 & 69 & 70 & 66 & 86 & 109 & 83 & 80 \\
Peru & 86 & 61 & 86 & 122 & 118 & 99 & 79 & 74 & 112 & 126 & 114 & 75 \\
Chile & 111 & 113 & 118 & 165 & 108 & 88 & 104 & 88 & 86 & 87 & 80 & 91 \\
Colombia & 87 & 86 & 102 & 140 & 151 & 152 & 103 & 114 & 78 & 89 & 96 & 92 \\
Mexico & 106 & 110 & 109 & 116 & 76 & 47 & 53 & 67 & 75 & 62 & 86 & 94 \\
Uruguay & 106 & 126 & 140 & 123 & 103 & 85 & 83 & 82 & 79 & 91 & 82 & 75 \\
Venezuela & 155 & 95 & 76 & 82 & 112 & 57 & 60 & 62 & 100 & 96 & 127 & 66 \\
\hline
\end{tabular}

Source: CEPAL, Economic Development Division. 
Table 9

LATIN AMERICA: RATIO OF PUBLIC EXTERNAL DEBT ${ }^{a}$ TO CURRENT PUBLIC REVENUES ${ }^{b}$ (Percentages)

\begin{tabular}{lrrrrrrrrrrrr}
\hline Countries & 1978 & 1979 & 1980 & 1981 & 1982 & 1983 & 1984 & 1985 & 1986 & 1987 & 1988 & 1989 \\
\hline Argentina & 41 & 34 & 27 & 41 & 125 & 196 & 164 & 223 & 195 & 245 & $\ldots$ & $\ldots$ \\
Bolivia & $\ldots$ & $\ldots$ & 269 & 424 & 785 & 1398 & 736 & 580 & 550 & 726 & $\ldots$ & $\ldots$ \\
Brazil & $\ldots$ & $\ldots$ & 64 & 66 & 76 & 125 & 147 & 140 & 114 & 120 & 107 & $\ldots$ \\
Costa Rica & $\ldots$ & $\ldots$ & 128 & 269 & 365 & 299 & 239 & 254 & 227 & 232 & $\ldots$ & $\ldots$ \\
Ecuador & $\ldots$ & 104 & 110 & 126 & 121 & 193 & 217 & 186 & 264 & 359 & $\ldots$ & $\ldots$ \\
Peru & $\ldots$ & $\ldots$ & 151 & 142 & 164 & 262 & 255 & 314 & 303 & 310 & 451 & 652 \\
Colombia & 60 & 55 & 63 & 83 & 82 & 106 & 91 & 141 & 151 & 166 & 155 & 160 \\
Chile & 87 & 64 & 47 & 45 & 66 & 96 & 162 & 210 & 230 & 213 & $\ldots$ & $\ldots$ \\
Mexico & $\ldots$ & $\ldots$ & 74 & 83 & 140 & 188 & 160 & 174 & 267 & 257 & 201 & 155 \\
Uruguay & 57 & 50 & 38 & 38 & 55 & 156 & 192 & 194 & 148 & 136 & $\ldots$ & $\ldots$ \\
Venezuela & $\ldots$ & $\ldots$ & 49 & 50 & 55 & 75 & 84 & 96 & 181 & 196 & $\ldots$ & $\ldots$ \\
& & $\ldots$ & & & & & & & \\
\hline
\end{tabular}

Source: CEPAL, Economic Development Division.

Public and publicly guaranteed debt: World Bank, World Debt Tables, 1990-1991,

Washington D.C., 1990.

b: Includes total revenues of the general government plus operating surplus (or deficit) of public enterprises.

$(\ldots)$ = Unavailable. 
Table 10

RATYO OF INTEREST ACCRUED ON PUBLIC FOREIGN DEBT AND DEFICIT OF NON-FINANCIAL PUBIIC SECTOR (Percentages)

\begin{tabular}{|c|c|c|c|c|c|c|c|c|c|c|}
\hline Countries & 1980 & 1981 & 1982 & 1983 & 1984 & 1985 & 1986 & 1987 & 1988 & 1989 \\
\hline \multicolumn{11}{|l|}{ Group I } \\
\hline $\begin{array}{l}\text { Argentina } \\
\text { Bolivia } \\
\text { Brazil } \\
\text { Costa Rica } \\
\text { Ecuador } \\
\text { Peru }\end{array}$ & $\begin{array}{r}8 \\
88 \\
136 \\
31 \\
34 \\
67\end{array}$ & $\begin{array}{r}7 \\
94 \\
54 \\
356 \\
39 \\
32\end{array}$ & $\begin{array}{r}13 \\
91 \\
48 \\
309 \\
61 \\
29\end{array}$ & $\begin{array}{r}22 \\
52 \\
67 \\
-944 \\
63 \\
33\end{array}$ & $\begin{array}{r}33 \\
21 \\
85 \\
-147 \\
600 \\
64\end{array}$ & $\begin{array}{r}64 \\
206 \\
68 \\
-194 \\
-2 \quad 891 \\
168\end{array}$ & $\begin{array}{r}79 \\
-78 \\
69 \\
-322 \\
159 \\
49\end{array}$ & $\begin{array}{r}54 \\
125 \\
63 \\
-218 \\
156 \\
23\end{array}$ & $\begin{array}{l}\ldots \\
\cdots \\
44 \\
\cdots \\
\ddot{2} 3\end{array}$ & $\begin{array}{l}\ldots \\
\ldots \\
\ldots \\
\cdots \\
23\end{array}$ \\
\hline \multicolumn{11}{|l|}{ Group II } \\
\hline $\begin{array}{l}\text { Colombia } \\
\text { Chile } \\
\text { Mexico } \\
\text { Uruguay } \\
\text { Venezuela }\end{array}$ & $\begin{array}{r}33 \\
-34 \\
27 \\
-108 \\
-24\end{array}$ & $\begin{array}{r}21 \\
-397 \\
14 \\
59 \\
-111\end{array}$ & $\begin{array}{l}23 \\
59 \\
24 \\
13 \\
26\end{array}$ & $\begin{array}{r}19 \\
79 \\
59 \\
90 \\
131\end{array}$ & $\begin{array}{r}20 \\
114 \\
60 \\
120 \\
-25\end{array}$ & $\begin{array}{r}59 \\
224 \\
53 \\
236 \\
-33\end{array}$ & $\begin{array}{r}848 \\
494 \\
33 \\
772 \\
241\end{array}$ & $\begin{array}{r}155 \\
-2 \quad 037 \\
31 \\
496 \\
-528\end{array}$ & $\begin{array}{c}125 \\
\ldots \\
41 \\
\ldots \\
\ldots\end{array}$ & $\begin{array}{l}155 \\
\cdots \\
65 \\
\ldots \\
\ldots\end{array}$ \\
\hline
\end{tabular}

Source: CEPAL, Economic Development Division. Note: $(-)=$ Surplus; $(\ldots)$ = Unavailable 
Table 11

LATIN AMERICA: ROLLOVER RATIO ON PUBLIC FOREIGN DEBT SERVICE (Percentages)

\begin{tabular}{|c|c|c|c|c|c|c|c|c|c|c|c|c|}
\hline Countries & 1978 & 1979 & 1980 & 1981 & 1982 & 1983 & 1984 & 1985 & 1986 & 1987 & 1988 & 1989 \\
\hline Argentina & 69 & 47 & 70 & 113 & 49 & 134 & 684 & 94 & 186 & 152 & 322 & 611 \\
\hline Bolivia & 67 & 81 & 66 & 75 & 139 & 197 & $18 A$ & 282 & 62 & 84 & 86 & 83 \\
\hline Brazil & 47 & 68 & 98 & 91 & 95 & 93 & 81 & 282 & 220 & 440 & 189 & 440 \\
\hline Costa Rica & 81 & 66 & 48 & 64 & 196 & 87 & 158 & 123 & 236 & 606 & 325 & 256 \\
\hline Ecuador & 39 & 87 & 57 & 59 & 400 & 197 & 120 & 148 & 86 & 156 & 151 & 162 \\
\hline Peru & 90 & 83 & 121 & 126 & 72 & 57 & 74 & 163 & 163 & 131 & 225 & 149 \\
\hline Colombia & 131 & 65 & 52 & 51 & 71 & 67 & 62 & 77 & 71 & 194 & 124 & 140 \\
\hline Chile & 83 & 93 & 160 & 152 & 79 & 49 & 76 & 90 & 151 & 185 & 123 & 247 \\
\hline Mexico & 74 & 95 & 86 & 61 & 79 & 159 & 220 & 269 & 264 & 125 & 220 & 331 \\
\hline Uruguay & 103 & 66 & 74 & 62 & 52 & 61 & 217 & 185 & 163 & 152 & 181 & 146 \\
\hline Venezuela & 30 & 40 & 103 & 113 & 140 & 111 & 363 & 727 & 714 & 556 & 186 & 207 \\
\hline
\end{tabular}


Table 12

LATIN AMERICA: RATIO OF NET FOREIGN TRANSFER OF RESOURCES TO THE PUBLIC SECTOR ${ }^{a}$ TO CURRENT PUBLIC REVENUES

(Percentages)

\begin{tabular}{|c|c|c|c|c|}
\hline \multirow[b]{2}{*}{ Countries } & \multicolumn{2}{|c|}{ Before the crisis } & \multicolumn{2}{|c|}{ During the crisis } \\
\hline & Period & Yearly average & Period & Yearly average \\
\hline Argentina & $80-82$ & 7 & $83-87$ & -7 \\
\hline Bolivia & $80-81$ & 16 & $\begin{array}{l}82-85 \\
86-87\end{array}$ & $\begin{array}{r}-28 \\
19\end{array}$ \\
\hline Brazil & $80-82$ & 1 & $\begin{array}{l}83-84 \\
85-88\end{array}$ & $\begin{array}{r}3 \\
-8\end{array}$ \\
\hline Costa Rica & $80-82$ & 12 & $83-87$ & -11 \\
\hline Ecuador & $80-81$ & 16 & $\begin{array}{l}82-85 \\
86-87\end{array}$ & $\begin{array}{r}-12 \\
4\end{array}$ \\
\hline Peru & $80-81$ & -8 & $\begin{array}{l}82-84 \\
85-89\end{array}$ & $\begin{array}{r}21 \\
4\end{array}$ \\
\hline Colombia & $80-82$ & 8 & $\begin{array}{l}83-86 \\
87-89\end{array}$ & $\begin{array}{r}8 \\
-10\end{array}$ \\
\hline Chile & $80-81$ & -5 & $\begin{array}{l}82-84 \\
85-87\end{array}$ & $\begin{array}{r}7 \\
-5\end{array}$ \\
\hline Mexico & $80-82$ & 6 & $\begin{array}{l}83-86 \\
87-89\end{array}$ & $\begin{array}{l}-15 \\
-11\end{array}$ \\
\hline Uruguay & $80-83$ & 6 & $84-87$ & -11 \\
\hline Venezuela & $80-83$ & -2 & $84-87$ & -14 \\
\hline
\end{tabular}

Source: CEPAL, on the basis of official data and data from the World Bank.

a: Interest and amortization payments by the public sector minus disbursements to the public sector.

b: Includes total revenues of the general government plus operating surplus (or deficit) of public enterprises. 
Table 13

LATIN AMERICA AAD THE CARIBBEAN: PERIOOS OF MORATORIUM

\begin{tabular}{lllllllll}
\hline 1982 & 1983 & 1984 & 1985 & 1986 & 1987 & 1988 & 1989 & 1990 \\
\hline
\end{tabular}

Dit-exporting countries

Bolivia

Ecuador

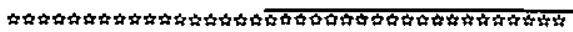

Peru

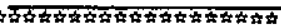

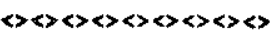

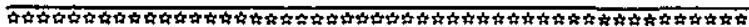

Venezuela

\langle\rangle\langle\rangle\langle\rangle\langle\rangle\langle\rangle\langle\rangle\langle\rangle\langle\rangle\langle\rangle\langle\rangle\langle\rangle\langle\rangle

Man-oil-exporting cosntries

Argent ina

Brazil

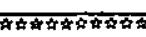

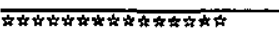

Paraguay

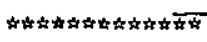

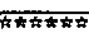

Costa Rica

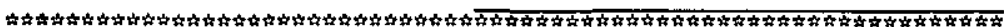

Cuba

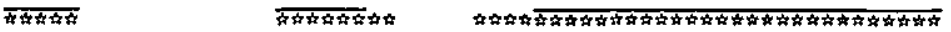

Dominican

Republ ic

El Salvador

Guatemala

Haiti

Honduras

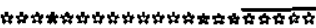

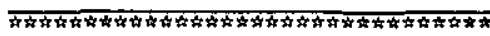

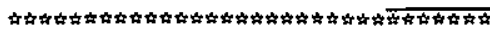

Nicaragua

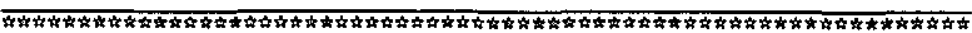

\langle\rangle\langle\rangle\langle\rangle\langle\rangle\langle\rangle\langle\rangle\langle\rangle\langle\rangle\langle\rangle\langle\rangle

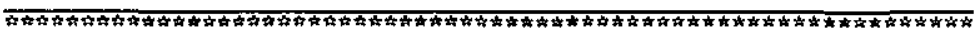

\langle\rangle\langle\rangle\langle\rangle\langle\rangle\langle\rangle\langle\rangle\langle\rangle\langle\rangle\langle\rangle\langle\rangle\langle\rangle\langle\rangle\langle\rangle\langle\rangle\langle\rangle\langle\rangle\langle\rangle\langle\rangle\langle\rangle\langle\rangle\langle\rangle\langle\rangle

Panama

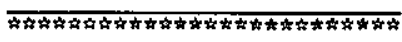

$\langle>\langle>\langle\rangle\langle\rangle\langle\rangle\langle\rangle\langle\rangle\langle\rangle\langle\rangle\langle\rangle\langle\rangle\langle\rangle\langle\rangle$

Source: CEPAL, on the basis of official data.

Symbols:

= Commercial banks

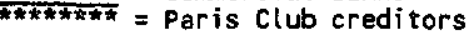

《<< = Multilateral creditors

........ = Incomplete information 
Table 14

LATIN AMERICA AND THE CARIBBEAN: ECONOMIC PERFOMANCE OF THE PROBLEM DEBTORS

\begin{tabular}{|c|c|c|c|c|}
\hline \multirow{2}{*}{$\begin{array}{l}\text { Growth } \\
\text { Inflation }\end{array}$} & \multicolumn{2}{|c|}{ sustained } & \multicolumn{2}{|c|}{ sporadic or not significant } \\
\hline & Moratorium & Non-moratorium & Moratorium & Non-moratorium \\
\hline $\begin{array}{l}\text { Relative } \\
\text { price } \\
\text { stability }\end{array}$ & $\begin{array}{l}\operatorname{CRI}(1986-90) \\
\operatorname{PAR}(1987-90)\end{array}$ & $\begin{array}{l}\operatorname{CHI}(1984-90) \\
\operatorname{MEX}(1989-90)\end{array}$ & $\begin{array}{l}\text { BOL }(1986-90) \\
\operatorname{CUBA}(1986-90) \\
\text { HON }(1982-90) \\
\operatorname{CRI}(1982-85)\end{array}$ & $\mathrm{CHI}(1982-83)$ \\
\hline $\begin{array}{l}\text { severe } \\
\text { or sharply } \\
\text { rising }\end{array}$ & GUAT (1987-90) & & $\begin{array}{l}\text { ARG (1983-84) } \\
\text { ARG (1988-90) } \\
\text { BRA (1987) } \\
\text { BRA (1989-90) } \\
\text { ECU (1987-90) } \\
\text { PER (1984-90) } \\
\text { BOL (1982-85) } \\
\text { NIC (1982-90) } \\
\text { DR ( } 1982-90) \\
\operatorname{PAR}(1982-85) \\
\text { EL SAL }(1985-90) \\
\text { HAI (1984-90) } \\
\text { GUAT (1984-86) }\end{array}$ & $\begin{array}{l}\operatorname{MEX}(1982-88) \\
\operatorname{VEN}(1982-90) a \\
\operatorname{URU}(1982-90)\end{array}$ \\
\hline
\end{tabular}

Source: CEPAL, Economic Development Division.

a: There were indications that in the coming years this country could join Chile and Mexico in the upper left-hand box. 
Table 15

SIX MORATORILM COUATRIES: MET TRANSFER OF RESCURCES

(Millions of dollars)

\begin{tabular}{|c|c|c|c|c|c|c|c|c|c|c|}
\hline Countries & 1982 & 1983 & 1984 & 1985 & 1986 & 1987 & $1988 \underline{c} /$ & $1989 \mathrm{~b} /$ & $1990 \mathrm{~b} /$ & $1991 \mathrm{~b} /$ \\
\hline \multicolumn{11}{|l|}{ Argentina } \\
\hline $\begin{array}{l}\text { Total } \\
\text { Credit }\end{array}$ & $\begin{array}{ll}-3 & 033 \\
-4 & 460\end{array}$ & $\begin{array}{ll}-5 & 429 \\
-5 & 880\end{array}$ & $\begin{array}{ll}-3 & 050 \\
-3 & 583\end{array}$ & $\begin{array}{ll}-3 & 321 \\
-2 & 778\end{array}$ & $\begin{array}{ll}-2 & 448 \\
-2 & 477\end{array}$ & $\begin{array}{ll}-2 & 162 \\
-1 & 271\end{array}$ & $\begin{array}{ll}-1 & 654 \\
-1 & 126\end{array}$ & $\begin{array}{ll}-6 & 465 \\
-6 & 534\end{array}$ & $\begin{array}{r}-4615 \\
\cdots\end{array}$ & $\begin{array}{c}-200 \\
\cdots\end{array}$ \\
\hline \multicolumn{11}{|l|}{ Bolivia } \\
\hline $\begin{array}{l}\text { Total } \\
\text { Credit }\end{array}$ & $\begin{array}{l}-182 \\
-237\end{array}$ & $\begin{array}{l}-117 \\
-200\end{array}$ & $\begin{array}{l}-55 \\
-80\end{array}$ & $\begin{array}{r}66 \\
-273\end{array}$ & $\begin{array}{r}274 \\
86\end{array}$ & $\begin{array}{l}201 \\
-73\end{array}$ & $\begin{array}{l}120 \\
-82\end{array}$ & $\begin{array}{r}41 \\
-24\end{array}$ & $\begin{array}{l}105 \\
\cdots\end{array}$ & $\begin{array}{l}295 \\
\ldots .\end{array}$ \\
\hline \multicolumn{11}{|l|}{ Brazi! } \\
\hline $\begin{array}{l}\text { Total } \\
\text { Credit }\end{array}$ & $\begin{array}{ll}-2 & 381 \\
-2 & 399\end{array}$ & $\begin{array}{ll}-6 & 060 \\
-5 & 110\end{array}$ & $\begin{array}{ll}-6 & 133 \\
-6 & 559\end{array}$ & $\begin{array}{ll}-11 & 414 \\
-10 & 328\end{array}$ & $\begin{array}{ll}-9 & 056 \\
-7 & 048\end{array}$ & $\begin{array}{ll}-6 & 747 \\
-5 & 034\end{array}$ & $\begin{array}{l}-14545 \\
-14423\end{array}$ & $\begin{array}{r}-99854 \\
\ldots\end{array}$ & $\begin{array}{c}-7044 \\
-.-\end{array}$ & $\begin{array}{c}-8550 \\
\ldots\end{array}$ \\
\hline \multicolumn{11}{|l|}{ Costa Rica } \\
\hline $\begin{array}{l}\text { Total } \\
\text { Credit }\end{array}$ & $\begin{array}{r}24 \\
-176\end{array}$ & $\begin{array}{r}39 \\
-145\end{array}$ & $\begin{array}{l}-109 \\
-366\end{array}$ & $\begin{array}{r}81 \\
-268\end{array}$ & $\begin{array}{r}11 \\
-241\end{array}$ & $\begin{array}{r}184 \\
-185\end{array}$ & $\begin{array}{r}285 \\
-237\end{array}$ & $\begin{array}{r}333 \\
-138\end{array}$ & $\begin{array}{l}188 \\
\cdots\end{array}$ & 315 \\
\hline \multicolumn{11}{|l|}{ Ecuador } \\
\hline $\begin{array}{l}\text { Total } \\
\text { Credit }\end{array}$ & $248^{2}$ & $\begin{array}{l}-561 \\
-991\end{array}$ & $\begin{array}{l}-777 \\
-627\end{array}$ & $\begin{array}{r}-956 \\
-1041\end{array}$ & $\begin{array}{r}-469 \\
583\end{array}$ & $\begin{array}{l}253 \\
895\end{array}$ & $\begin{array}{l}-353 \\
-152\end{array}$ & $\begin{array}{l}-306 \\
-294\end{array}$ & $\begin{array}{l}-435 \\
-. .\end{array}$ & $\begin{array}{r}-415 \\
-.-\end{array}$ \\
\hline \multicolumn{11}{|l|}{ Peru } \\
\hline $\begin{array}{l}\text { Total } \\
\text { Ĉredit }\end{array}$ & $\begin{array}{l}658 \\
962\end{array}$ & $\begin{array}{r}-72 \\
-316\end{array}$ & $\begin{array}{r}-535 \\
15\end{array}$ & $\begin{array}{l}-816 \\
-580\end{array}$ & $\begin{array}{l}113 \\
-71\end{array}$ & $\begin{array}{l}275 \\
159\end{array}$ & $\begin{array}{l}480 \\
446\end{array}$ & $\begin{array}{l}-422 \\
-211\end{array}$ & 365 & $\begin{array}{c}1790 \\
\ldots\end{array}$ \\
\hline
\end{tabular}

a: Total transfer is net capital flows less net factor payments. Credit transfer is net medium, long and short term loans less interest payments.

b: Preliminary.

(-.) : not available 
A $\mathbb{N} \mathbb{E} \mathbb{X}$ 

ANNEX I

Table IA

LATIN AMERICA: INTEREST ARREARS WITH COMMERCIAL BANKS

(Millions of dollars)

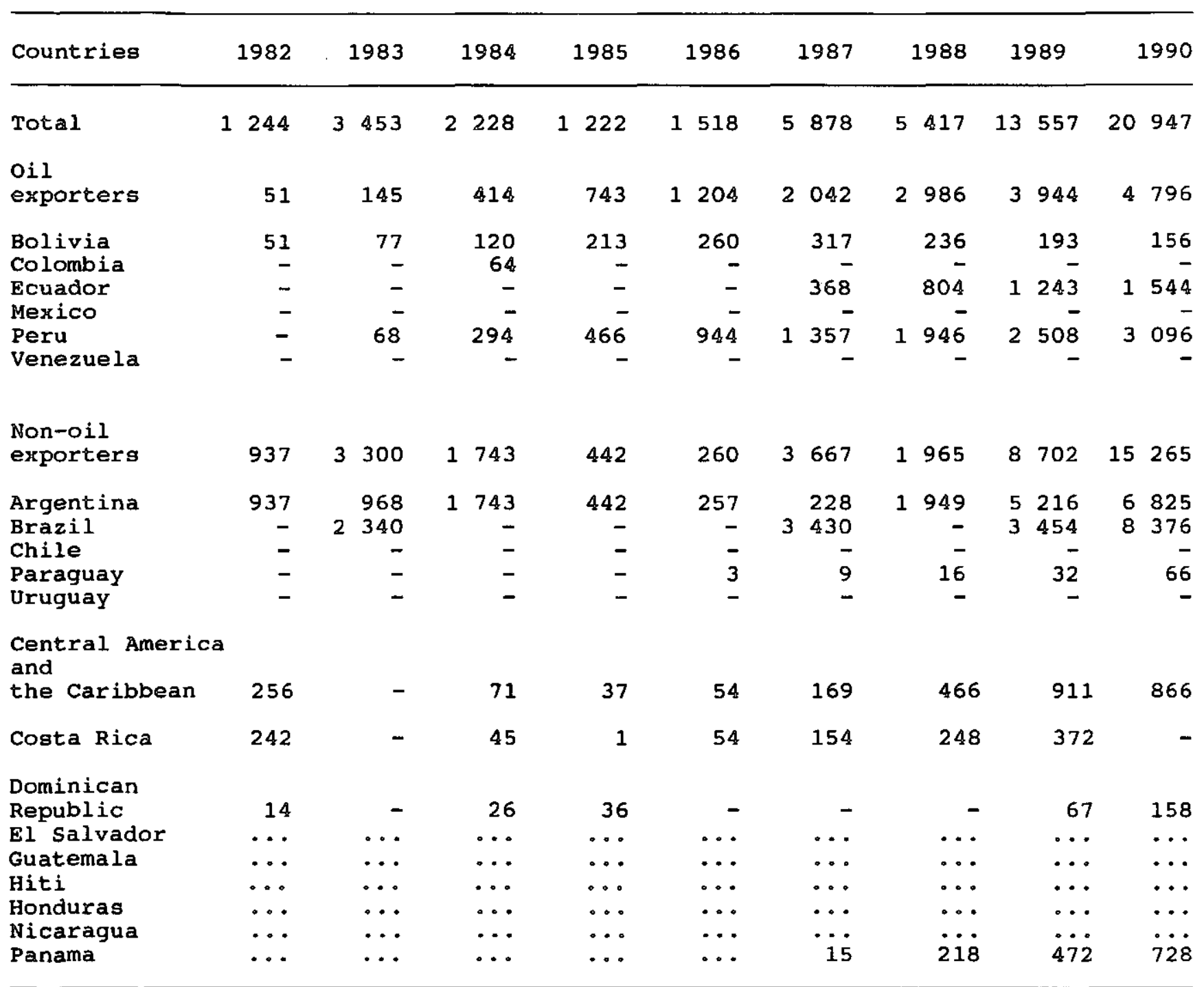

Source: Institute of Internacional Finance. 



\section{IBiblolography}

Abbate, Francesco, Roger Lawrence and Anne Miroux (1992), "Atrasos de los países de América Latina con los acreedores del Club de París: problemas y opciones", in Oscar Altimir and Robert Devlin (eds.), Moratoria de la deuda en América Latina: experiencia de los países, (forthcoming publication of Fondo de Cultura Económica, Mexico City).

Altimir, Oscar, (1990) "Development, Crisis and Equity", in ECLAC Review No.40, Santiago, Chile.

Bianchi, Andrés, Robert Devlin and Joseph Ramos, (1987) "El proceso de ajuste en la América Latina. 1981-1986", in El Trimestre Económico, Vol. LIV(4), No.216, Mexico, October.

Biggs, Gonzalo (1992), "Cobro judicial de la deuda pública externa morosa de América Latina: derechos y defensas de las partes", in Oscar Altimir and Robert Devlin (eds.), Moratoria de la deuda en América Latina: experiencia de los países, 1992 (forthcoming publication of Fondo de Cultura Económica, Mexico City).

Bouzas, Roberto and Saul Keifman (1988), "Las negociaciones financieras externas de la Argentina en el período 1982-1987", in Roberto Bouzas (ed.), Entre la heterodoxia y el ajuste, Grupo Editor Latinoamericano, Buenos Aires, pp. 27-72.

Cariaga, Juan (1992), "La moratoria boliviana y el ajuste económico exitoso", in Oscar Altimir and Robert Devlin (eds.), Moratoria de la deuda en América Latina: experiencia de los países (forthcoming publication of Fondo de Cultura Económica, Mexico City).

Castro, Fidel (1985), How Latin Debr Should be Cancelled and the Pressing Need for the New International Economic Order, Interview Granted to the Mexican Daily Excelsior, Havana: Editora Política.

Cline, William (1984), International Debt: Systemic Risk and Policy Response, Washington D.C., Institute for International Economics.

De Freitas, Carlos (1992), "Breve historia de las moratorias brasileñas", in Oscar Altimir and Robert Devlin (eds.), Moratoria de la deuda en América Latina: experiencia de los países (forthcoming publication of Fondo de Cultura Económica, Mexico City).

Devlin, Robert (1989), Debt and Crisis in Latin America: the Supply Side of the Story, Princeton University Press, Princeton.

ECLAC (1965), External Financing in Latin America, New York. 
(1978) Tendencias y proyecciones a largo plazo del desarrollo económico de América Latina, (L/ECLAC 1027),

(1985), External Debt in Latin America, Lynne Rienner Publishers, Boulder, Colorado.

(1988), The Evolution of the External Debt Problem in Latin America, Santiago, Chile.

(1989), Economic Survey of Latin America and the Caribbean 1988, Santiago, Chile.

(1990a), Latin America and the Caribbean: Options to Reduce the Debt Burden, in Libros de la CEPAL, No.26, Santiago, Chile.

(1990b), Preliminary Overview of the Economy of Latin America and the Caribbean 1990, Santiago, Chile.

(1990c), Economic Survey of Latin America and the Caribbean 1989, Santiago, Chile.

Fanelli, José María, Roberto Frenkel and Guillermo Rozenwurcel, (1990), Growth and Structural Reform in Latin America. Where we Stand, in CEDES, Documento No.57, Buenos Aires.

Ffrench-Davis, R. (1986), "Notas sobre el desarrollo económico y la deuda externa en América Latina", in Desarrollo Económico: Revista de Ciencias Sociales, No.100, Vol.25, Instituto de Desarrollo Económico y Social, Buenos Aires, enero-marzo.

Figueroa, Leonel, (1992) "Administración de la moratoria peruana", in Oscar Altimir and Robert Devlin (eds.), Moratoria de la deuda en América Latina: experiencia de los países (forthcoming publication of Fondo de Cultura Económica, Mexico City).

Fosatti, Fabio (1991), "Debt Adjustment and Conflict: A Comparative Analysis of Argentina, Peru, and Venezuela", Department of Political Science, University of Florencia, Italy.

Friedman, Irving (1980), "The New Climate for Evaluating Country Risk", International Bankers Roundtable, Cannes, France, 12-14 June, 47 pp.

Frohmann, Alicia (1986), Democracia, deuda externa y disciplinamiento económico: las relaciones entre Argentina y Estados Unidos, 1983-1985, in FLACSO Working Paper No.298, Santiago, Chile, June.

, (1989), Actores privados y estatales en la relación Argentina-Estados Unidos, in CERIR, Estudio No.5, Rosario, Argentina, September.

Galbraith, John Kenneth (1975), Money, Houghton Mifflin, Boston. 
Hector, Gary (1985), "The Third World Debt Problem: the Bomb is Defused", in Fortune, 18 February 1985, pp. 36-50.

Institute of International Finance (1990), "Improving the Official Debt Strategy: Arrears are Not the Way", Washington D.C.

Kaufman, Robert and Barbara Stallings (1989), "Debt and Democracy in the 1980s: The Latin American Experience", in Barbara Stallings and Robert Kaufman (eds.), Debt and Democracy in Latin America, Westview Press, Boulder, Colorado, pp. 7-22.

Khan, Moshin (1990), "The Macroeconomic Effects of Fund-Supported Adjustment Programs", in IMF Staff Papers, Vol. 37, No.2, June, pp. 195-231.

Kindleberger, Charles (1978), Manias, Panics \& Crashes, Basic Books, New York.

Krueger, Anne, O., (1987), "Origins of the Developing Countries", in Journal of Development Economics, Vol 27, No. 1 and 2 (special issue), October.

Latin American Weekly Report (1989), "Amid the Non-News About Brazil's Non-Payment; an Internal Threat", 28 September. , (1990), "Peru, Court Action by United States Creditors", 15 March.

LDC Debt Report, (1991), Washington D.C., April.

Machinea, José Luis and Juan Sommer (1992), "El manejo de la deuda externa en condiciones de crisis en la balanza de pagos: la moratoria argentina, 1988-1989", in Oscar Altimir and Robert Devlin (eds.), Moratoria de la deuda en América Latina: experiencia de los países, (forthcoming publication of Fondo de Cultura Económica, Mexico City).

O'Connell, Arturo, (1992) "Mora con las instituciones financieras internacionales", in Oscar Altimir and Robert Devlin (eds.), Moratoria de la deuda en América Latina: experiencia de los países (forthcoming publication of Fondo de Cultura Económica, Mexico City).

Rodríguez, Ennio (1992), "Administración de las restricciones unilaterales de pago y desarrollo: el caso de Costa Rica", in Oscar Altimir and Robert Devlin (eds.), Moratoria de la deuda en América Latina: experiencia de los países (forthcoming publication of: Fondo de Cultura Económica, Mexico City).

Simonsen, Mario H., (1985), "The Developing-Country Debt Problem", in Gordon W. Smith and John T. Cuddington (Eds.), International Debt and the Developing Countries, World Bank, Washington D.C. 
Skidmore, David (1987), "Banks' Loss is First in 50 Years", in Washington Post, 16 September.

Skiles, Marilyn (1988), "Latin American International Loan Defaults in the 1930s; Lessons for the 1980s?", in Federal Reserve Bank of New York, Research Paper No.8812, April.

Stallings, Barbara (1990), "Comment", in John Williamson (ed.), Latin American Adjustment, Institute for International Economics, Washington, D.C., pp. 98-102.

The Economist, (1990), "Blind Man's Bluff", 27 October.

Tussie, Diana (1988), "La coordinación de los deudores latinoamericanos: Cuál es la lógica de su accionar?" in Stephany Griffith-Jones (ed.), Deuda externa, renegociación y ajuste en América Latina. Fondo de Cuitura Económica, México, pp. 280-301.

Wellons, Philip (1987), Passing the Buck, Harvard, Business School Press, Boston, Harvard.

West, Peter (1991), "Retorno de América Latina al mercado de capitales privados", Revista de la CEPAL, No.44, August.

Williamson, John (1990), The Progress of Policy Reform in Latin America, Institute of International Economics, Washington D.C.

Yepez, Mauricio (1992), "Administración de la restricción de la deuda externa ecuatoriana", in Oscar Altimir and Robert Devlin (eds.), Moratoria de la deuda en América Latina: experiencia de los países (forthcoming publication of Fondo de Cultura Económica, Mexico City). 


